\title{
The influence of ocean acidification on nitrogen regeneration and nitrous oxide production in the northwest European shelf sea
}

\author{
D. R. Clark, I. J. Brown, A. P. Rees, P. J. Somerfield, and P. I. Miller \\ Plymouth Marine Laboratory, Prospect Place, The Hoe, Plymouth, PL1 3DH, UK \\ Correspondence to: D. R. Clark (drcl@pml.ac.uk)
}

Received: 18 December 2013 - Published in Biogeosciences Discuss.: 25 February 2014

Revised: 31 July 2014 - Accepted: 14 August 2014 - Published: 18 September 2014

\begin{abstract}
The assimilation and regeneration of dissolved inorganic nitrogen, and the concentration of $\mathrm{N}_{2} \mathrm{O}$, was investigated at stations located in the NW European shelf sea during June/July 2011. These observational measurements within the photic zone demonstrated the simultaneous regeneration and assimilation of $\mathrm{NH}_{4}^{+}, \mathrm{NO}_{2}^{-}$and $\mathrm{NO}_{3}^{-}$. $\mathrm{NH}_{4}^{+}$was assimilated at $1.82-49.12 \mathrm{nmol} \mathrm{NL}^{-1} \mathrm{~h}^{-1}$ and regenerated at $3.46-14.60 \mathrm{nmol} \mathrm{N} \mathrm{L}^{-1} \mathrm{~h}^{-1} ; \mathrm{NO}_{2}^{-}$was assimilated at $0-2.08 \mathrm{nmolN} \mathrm{L}^{-1} \mathrm{~h}^{-1}$ and regenerated at $0.01-1.85 \mathrm{nmol} \mathrm{NL}^{-1} \mathrm{~h}^{-1} ; \mathrm{NO}_{3}^{-}$was assimilated at $0.67-18.75 \mathrm{nmol} \mathrm{N} \mathrm{L}^{-1} \mathrm{~h}^{-1}$ and regenerated at $0.05-$ $28.97 \mathrm{nmolNL}^{-1} \mathrm{~h}^{-1}$. Observations implied that these processes were closely coupled at the regional scale and that nitrogen recycling played an important role in sustaining phytoplankton growth during the summer. The $\left[\mathrm{N}_{2} \mathrm{O}\right]$, measured in water column profiles, was $10.13 \pm 1.11 \mathrm{nmol} \mathrm{L}^{-1}$ and did not strongly diverge from atmospheric equilibrium indicating that sampled marine regions were neither a strong source nor sink of $\mathrm{N}_{2} \mathrm{O}$ to the atmosphere. Multivariate analysis of data describing water column biogeochemistry and its links to $\mathrm{N}$-cycling activity failed to explain the observed variance in rates of $\mathrm{N}$-regeneration and $\mathrm{N}$-assimilation, possibly due to the limited number of process rate observations. In the surface waters of five further stations, ocean acidification (OA) bioassay experiments were conducted to investigate the response of $\mathrm{NH}_{4}^{+}$oxidising and regenerating organisms to simulated OA conditions, including the implications for $\left[\mathrm{N}_{2} \mathrm{O}\right]$. Multivariate analysis was undertaken which considered the complete bioassay data set of measured variables describing changes in N-regeneration rate, $\left[\mathrm{N}_{2} \mathrm{O}\right]$ and the biogeochemical composition of seawater. While anticipating biogeochemical differences between locations, we aimed to test the hypothesis that the underlying mechanism through
\end{abstract}

which pelagic $\mathrm{N}$-regeneration responded to simulated OA conditions was independent of location. Our objective was to develop a mechanistic understanding of how $\mathrm{NH}_{4}^{+}$regeneration, $\mathrm{NH}_{4}^{+}$oxidation and $\mathrm{N}_{2} \mathrm{O}$ production responded to $\mathrm{OA}$. Results indicated that $\mathrm{N}$-regeneration process responses to $\mathrm{OA}$ treatments were location specific; no mechanistic understanding of how $\mathrm{N}$-regeneration processes respond to OA in the surface ocean of the NW European shelf sea could be developed.

\section{Introduction}

The release of $\mathrm{CO}_{2}$ to the atmosphere from the combustion of fossil fuels and its dissolution within the surface ocean has led, through a series of chemical reactions, to a decrease in seawater $\mathrm{pH}$ of 0.1 units since pre-industrial times (Orr et al., 2005). With few exceptions, this change exceeds that of any in the last 300 million years, and is projected to continue and to influence progressively greater depths of the world's ocean (Caldeira and Wickett, 2003). The majority of marine biota reside in the surface ocean and are exposed to this progressive decrease in seawater $\mathrm{pH}$, termed ocean acidification (OA). This includes the microbes which collectively support marine food webs. The activity of marine biota influences the composition of dissolved chemicals and particulate organic material such as phytoplankton cells and faecal pellets. Through their activity, the marine biota moderate the exchange of elements such as carbon, nitrogen and phosphorous between the ocean surface and its interior and also of gases between the surface ocean and lower atmosphere. Consequently, biological activity within the surface ocean plays a pivotal role in supporting complex marine food 
webs, in moderating the gaseous composition of the Earth's atmosphere and in the sequestration and export of anthropogenic carbon to the deep ocean, effectively removing it from biological activity for geological timescales. The way in which marine biota respond to OA will have profound implications for both the short-term exploitation of marine services by human activity (Cooley et al., 2009) and also for the oceans' capacity to sequester anthropogenic $\mathrm{CO}_{2}$ over longer timescales.

Biogeochemical investigations of the pelagic environment, or physiological investigations of the micro-organisms which inhabit this region in the case of laboratory culture studies, present a complex view of the response of marine biota to projected OA conditions (Riebesell et al., 2008; Flynn et al., 2012; Clark et al., 2014). At the organismal level there will undoubtedly be those for which projected changes to seawater carbonate chemistry and $\mathrm{pH}$ will be advantageous while others will be placed at a disadvantage (Hutchins et al., 2009). Nonetheless, generalisations such as the influence of OA upon coccolithophorids remain elusive (Ridgwell et al., 2009; Beaufort et al., 2011). How potential impacts at the organismal level will propagate throughout microbial communities and translate into biogeochemical consequences at the ecosystem level is a topic of ongoing investigation. To this end, research programmes such as the European Project on ocean acidification (EPOCA; Gattuso and Hansson, 2009) were designed using a combination of laboratory-based culture, mesocosm and field campaigns. More recently, the United Kingdom Ocean Acidification (UKOA) Programme adopted a ship-based approach in order to undertake bioassay investigations of the pelagic community's response to simulated OA conditions at discrete geographical locations; here the findings from an investigation of nitrogen cycle processes within the NW European shelf sea is reported.

Shelf seas contribute disproportionately to the global carbon cycle by supporting up to $20 \%$ of global productivity while representing $<5 \%$ of global surface area (Jahnke, 2010; Liu et al., 2010). The NW European shelf sea system is characterised by seasonal transitions in water column biogeochemistry, with changes in nutrient availability, notably of nitrogen, exerting a significant influence on the rate and extent of phytoplankton growth (Riegman et al., 1998; Rees et al., 2002; Wafar et al., 2004). Nitrogen has five oxidation states and is available to marine microbes as inorganic, organic and gaseous forms; consequently there is considerable potential for environmental change to influence how nitrogen flows through marine systems. Considering only microbial processes, dissolved nitrogen gas $\left(\mathrm{N}_{2}\right)$ is made biologically available through the process of $\mathrm{N}_{2}$ fixation, which has been observed in the NW European shelf sea during summer (Rees et al., 2009). The subsequent release of fixed nitrogen as $\mathrm{NH}_{4}^{+}$and dissolved organic nitrogen (DON) can support microbial growth (Mulholland et al., 2006). Heterotrophic degradation of DON, through the activity of extracellular hydrolytic enzymes for example (Piontek et al., 2013), regenerates $\mathrm{NH}_{4}^{+}$within the pelagic environment while the oxidation of $\mathrm{NH}_{4}^{+}$to $\mathrm{NO}_{2}^{-}$and $\mathrm{NO}_{3}^{-}$by nitrifying organisms (i.e. nitrification; Wuchter et al., 2006; Herfort et al., 2007) provides oxidised inorganic nitrogen for autotrophic assimilation. Consequently, pelagic nitrogen regenerating processes directly influence the concentration and composition of the dissolved inorganic nitrogen (DIN) pool, which in turn directly influences the rate, extent and composition of phytoplankton community growth (Riegman and Noordeloos, 1998; Riegman et al., 1998; Maguer et al., 1999; Rees et al., 2002; Maguer et al., 2011). Even if phytoplankton communities prove to have a high resilience to the direct effects of OA, their growth may be indirectly affected via changes in the DIN pool if nitrogen regeneration processes themselves are significantly influenced by OA.

Somewhat surprisingly, there are few studies which have investigated the potential influence of OA upon nitrogen cycle processes, although nitrogen regeneration responses have been inferred during mesocosm studies (Schulz et al., 2008; Piontek et al., 2013). The process of $\mathrm{NH}_{4}^{+}$oxidation (i.e. the first stage of nitrification) is of particular interest as it is a significant marine source of the greenhouse gas nitrous oxide $\left(\mathrm{N}_{2} \mathrm{O}\right)$. An OA-related inhibition of $\mathrm{NH}_{4}^{+}$oxidation was reported for samples derived from below the euphotic zone at locations in the Atlantic and Pacific oceans (depths between 45 and $240 \mathrm{~m}$; Beman et al., 2011), although contradictory results were reported for numerous sites within a shallow coastal system (depths < $15 \mathrm{~m}$; Fulweiler et al., 2011), indicating that further investigation is required.

The aims of this study were to investigate how $\mathrm{N}$ regeneration within the surface ocean responds to projected OA conditions, including the consequences for the production of $\mathrm{N}_{2} \mathrm{O}$, by undertaking acidification bioassay experiments at a range of NW European shelf locations. We aimed to test the hypothesis that the underlying mechanism through which pelagic $\mathrm{N}$-regeneration responded to simulated OA conditions was independent of location. Specifically, we hypothesised that simulated OA conditions would modify Nregeneration activity, leading to changes in the concentration and composition of the dissolved inorganic nitrogen pool. Our objective was to develop a mechanistic understanding of how $\mathrm{NH}_{4}^{+}$oxidation, $\mathrm{NH}_{4}^{+}$regeneration and $\mathrm{N}_{2} \mathrm{O}$ production responded to $\mathrm{OA}$. Additional observations of shelf sea nitrogen cycle processes and $\mathrm{N}_{2} \mathrm{O}$ concentration profiles were made to provide context to $\mathrm{OA}$ experiments.

\section{Materials and methods}

Investigations were undertaken during the UK Ocean Acidification cruise aboard RRS Discovery (D366) during 6 June to 12 July 2011, which departed from and returned to Liverpool, UK. A total of 75 CTD casts were undertaken at stations in the NW European shelf sea, from which 10 were sampled for observational nitrogen cycling studies (Sects. 2.2 


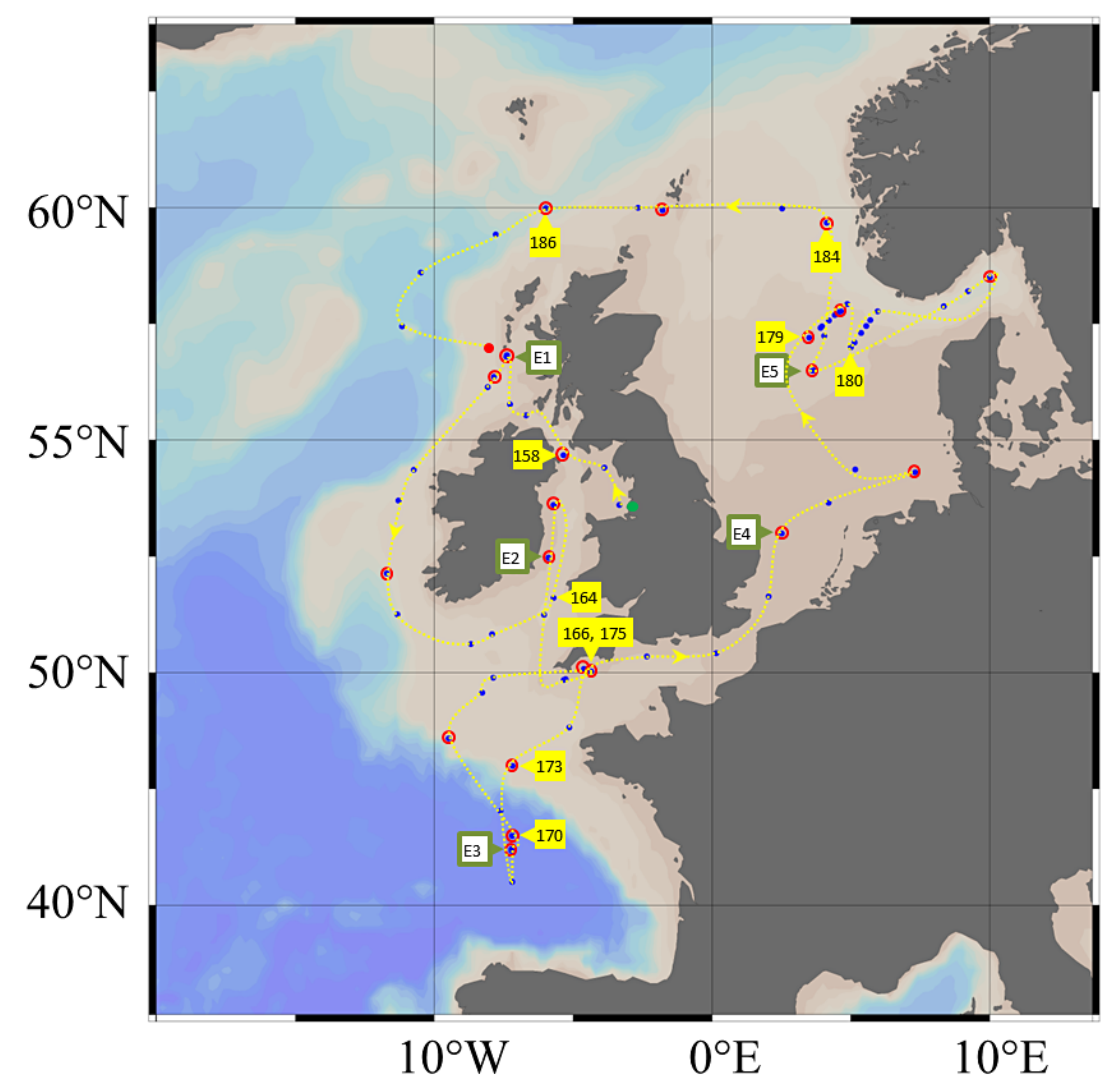

Figure 1. Station locations sampled within the NW European shelf sea area; stations for temperature and nutrient profiles (Fig. 3) are represented by blue circles; stations for $\mathrm{N}_{2} \mathrm{O}$ profiles (Fig. 3) are represented by open red circles; stations for nitrogen cycle measurements (Figs. 4, 5) are represented by yellow-box arrows which include Julian day; ocean acidification bioassay experiments (Figs. 8, 9) are represented by green-box arrows.

and 2.3), 34 were sampled for observational $\mathrm{N}_{2} \mathrm{O}$ concentration profiles (Sect. 2.4) and 5 were used for ocean acidification bioassay experiments (Sect. 2.5). The cruise track is identified in Fig. 1 which includes the location of sampling stations.

\subsection{Earth observation images}

Sea-surface temperature data were generated from Advanced Very High Resolution Radiometer (AVHRR) data on NOAA satellites, acquired by NEODAAS-Dundee, and processed using the Panorama system (Miller et al., 1997). The NOAA non-linear SST (NLSST) algorithm was applied and the 7day median composite used to reduce the effect of clouds. Ocean colour data from the Moderate Resolution Imaging Spectroradiometer (MODIS) sensor on the Aqua satellite were acquired from NASA OceanColor Website and processed to version R2013.0 using the PML Generic Earth Observation Processing System (GEOPS; Shutler, et al., 2005). Chlorophyll $a$ concentration was estimated using the OC3M algorithm, and a 7-day median composite calculated from the cloud-free pixels to gain a synoptic view. The enhanced colour view to identify the presence of coccoliths was ob- tained from 7-day median composites of remote sensing reflectance at 547, 488 and $443 \mathrm{~nm}$, combined as the red, green and blue channels respectively of an RGB image; hence the green-blue section of the visible spectrum was enhanced.

\subsection{Observational nitrogen cycle investigations}

Seawater was collected from specific depths using $20 \mathrm{~L}$ Niskin bottles mounted to a 24-way stainless steel rosette. Additional instrumentation was attached to the rosette for water column characterisation, which included Seabird conductivity, temperature, depth (CTD) units, a Seabird dissolved oxygen sensor and a Chelsea MKIII Aquatracka fluorometer. Seawater was collected during pre-dawn casts (approximately 4.30 a.m. GMT) at a depth equivalent to $55 \%$ of the surface photosynthetically active radiation (SPAR) value. Light attenuation water column profiles from the previous day were used to derive this depth, which corresponded to $5 \mathrm{~m}$ on average, but were consistently $<10 \mathrm{~m}$. Samples were not pre-filtered to remove particles of any size prior to N-regeneration studies; no information on particle density was available. Incubation bottles were not rotated to avoid particle settling during these incubations. Using ${ }^{15} \mathrm{~N}$-based 
methods, investigations were undertaken to determine the rate of $\mathrm{NH}_{4}^{+}$regeneration, $\mathrm{NH}_{4}^{+}$and $\mathrm{NO}_{2}^{-}$oxidation with simultaneous determinations of $\mathrm{NH}_{4}^{+}, \mathrm{NO}_{2}^{-}$and $\mathrm{NO}_{3}^{-}$assimilation, using methods described in Clark et al. (2006, 2007, 2011), updated and summarised below. All glassware used for the manipulation of seawater was cleaned with $10 \% \mathrm{HCL}$ (reagent grade, $37 \%$ ) between CTD sampling iterations and rinsed thoroughly with Milli-Q high purity water within iterations. All chemicals and solvents were analytical and highperformance liquid chromatography (HPLC) grade respectively, supplied by Sigma-Aldrich (UK) unless otherwise stated. Stable isotope salts $\left({ }^{15} \mathrm{NH}_{4} \mathrm{Cl}, \mathrm{Na}^{15} \mathrm{NO}_{3}, \mathrm{Na}^{15} \mathrm{NO}_{2}\right)$ were supplied by $\mathrm{CK}$ gas products Ltd (UK).

A $20 \mathrm{~L}$ volume of seawater collected in a blacked-out container from the $55 \%$ sPAR depth was used for assimilation and regeneration process studies, which ran in parallel, though of differing durations. As an overview, $6 \mathrm{~L}$ of this seawater was used for nitrogen assimilation studies while $12 \mathrm{~L}$ was used to determine the rate of nitrogen regeneration. $\mathrm{N}$ assimilation was determined by measuring the ${ }^{15} \mathrm{~N}$ enrichment of particulate material following incubation with seawater enriched with either ${ }^{15} \mathrm{NH}_{4}^{+},{ }^{15} \mathrm{NO}_{2}^{-}$or ${ }^{15} \mathrm{NO}_{3}^{-}$. For the determination of $\mathrm{N}$-regeneration rates, the DIN pool was enriched with either ${ }^{15} \mathrm{NH}_{4}^{+},{ }^{15} \mathrm{NO}_{2}^{-}$or ${ }^{15} \mathrm{NO}_{3}^{-}$and the dilution of this tracer due to $\mathrm{NH}_{4}^{+}$regeneration, $\mathrm{NH}_{4}^{+}$oxidation or $\mathrm{NO}_{2}^{-}$oxidation respectively was determined following a period of incubation. For N-regeneration methods, indophenol (derived from $\mathrm{NH}_{4}^{+}$) and sudan-1 (derived from $\mathrm{NO}_{2}^{-}$, or $\mathrm{NO}_{3}^{-}-\mathrm{N}$ following quantitative reduction to $\mathrm{NO}_{2}^{-}$) were synthesised from the seawater DIN pool. These products are readily formed at room temperature, are stable, are amenable to extraction from a seawater matrix, and are also amenable to purification and analysis using the methods described.

$\mathrm{NH}_{4}^{+}$regeneration rate was determined by amending a $4 \mathrm{~L}$ volume of seawater in a blacked-out container with ${ }^{15} \mathrm{NH}_{4}^{+}$at $<10 \%$ of the ambient concentration. On average, a $5.76 \pm 2.38 \%$ (ambient range $120-795 \mathrm{nmol} \mathrm{N} \mathrm{L}^{-1}$ ) enrichment was achieved for these studies. This volume was thoroughly mixed and placed for 5 min in a constant temperature room, which matched local surface seawater temperature, in order to ensure homogeneity. Amended seawater was then used to fill a $2.2 \mathrm{~L}$ incubation bottle, which was placed in a deck incubator at simulated light and temperature for approximately $24 \mathrm{~h}$. The remaining amended seawater was filtered through GF/F glass fibre filters and triplicate volumes between $100-300 \mathrm{~mL}$ (varying with ambient concentration) were set aside for the determination of pre-incubation $\mathrm{NH}_{4}^{+}$concentration and isotopic enrichment as described below. Following the deck incubation, bottle contents were filtered through GF/F filters and the filtrate was distributed between triplicate volumes of $100-300 \mathrm{~mL}$ (varying with ambient concentration) for the determination of post-incubation $\mathrm{NH}_{4}^{+}$concentration and isotopic enrichment.
An identical procedure was used for $\mathrm{NH}_{4}^{+}$and $\mathrm{NO}_{2}^{-}$oxidation incubations in which separate $4 \mathrm{~L}$ volumes of seawater were amended with ${ }^{15} \mathrm{NO}_{2}^{-}$and ${ }^{15} \mathrm{NO}_{3}^{-}$respectively. Average enrichments for these incubations were $10 \pm 6.9 \%$ (ambient range 9-66 $\mathrm{nmolNL}^{-1}$ ) and $12.7 \pm 2.2 \%$ (ambient range $43-955 \mathrm{nmol} \mathrm{N} \mathrm{L}^{-1}$ ) respectively. The concentration and isotopic enrichment of $\mathrm{NO}_{2}^{-}$was determined by synthesising sudan-1 in sample volumes of $100-200 \mathrm{~mL}$ depending on ambient concentration, as described below. The concentration and isotopic enrichment of $\mathrm{NO}_{3}^{-}$was determined by first reducing $\mathrm{NO}_{3}^{-}$to $\mathrm{NO}_{2}^{-}$using a high-capacity cadmium column, and then synthesising sudan-1 in volumes of $50-100 \mathrm{~mL}$ varying with ambient concentration, as described below.

Indophenol was synthesised in samples by adding the first reagent $(4.7 \mathrm{~g}$ phenol and $0.32 \mathrm{~g}$ sodium nitroprusside in $200 \mathrm{~mL}$ Milli-Q water) in the proportion of $1 \mathrm{~mL}$ per $100 \mathrm{~mL}$ of sample volume, mixing the sample and leaving for $5 \mathrm{~min}$. The second reagent (1.2 $\mathrm{g}$ sodium dichloroisocyanurate and $2.8 \mathrm{~g}$ sodium hydroxide in $200 \mathrm{~mL}$ Milli-Q) was then added in the proportion of $1 \mathrm{~mL}$ per $100 \mathrm{~mL}$ sample volume, mixed and left for $8 \mathrm{~h}$ at room temperature for indophenol development. Indophenol was collected by solid-phase extraction (SPE) as described below. Sudan-1 was synthesised by adding the first reagent $(0.8 \mathrm{~g}$ of aniline sulfate in $200 \mathrm{~mL} \mathrm{3M}$ $\mathrm{HCl}$ ) to samples in the proportion $0.5 \mathrm{~mL}$ per $100 \mathrm{~mL}$ sample volume, mixing, leaving for $5 \mathrm{~min}$ and then verifying that the $\mathrm{pH}$ was <2.0. Reagent $2(24 \mathrm{~g} \mathrm{NaOH}$ and $0.416 \mathrm{~g}$ 2-napthol in $200 \mathrm{~mL}$ Milli-Q) was added in the proportion $0.5 \mathrm{~mL}$ per $100 \mathrm{~mL}$ sample volume, mixing, leaving for $5 \mathrm{~min}$ and then verifying that sample $\mathrm{pH}$ was approximately 8.0. Sudan-1, the development of which was complete after $30 \mathrm{~min}$ of incubation at room temperature, was collected by SPE as described below.

Deuterated internal standards were added to samples immediately prior to SPE collection. The major advantage of this step was to minimise error associated with recovery efficiency. A full consideration of error and precision during SPE sample collection is provided in Clark et al. (2007). Deuterated indophenol and deuterated sudan-1 were synthesised according to methods described previously (Clark et al., 2006, 2007) and purified by HPLC as described below. Standard solutions in methanol were prepared $\left(100 \mathrm{ng} \mathrm{LL}^{-1}\right)$ and the concentration verified against analytical standard solutions (Sigma-Aldrich). In-house synthesis and verification proved to be a cost-effective alternative to the direct use of analytical standard solutions due to volume requirements. Appropriate volumes of deuterated internal standards (i.e. comparable to samples size) were added to samples following acidification by citric acid and prior to SPE collection.

Indophenol and sudan-1 were collected by SPE using $6 \mathrm{~mL} / 500 \mathrm{mg} \mathrm{C} 18$ cartridges (Biotage, UK) which were prepared for sample collection by first rinsing with $5 \mathrm{~mL}$ methanol, $5 \mathrm{~mL}$ Milli-Q water and $5 \mathrm{~mL} 0.2 \mu \mathrm{m}$ filtered 
seawater. Prior to sample collection seawater samples were acidified with $1 \mathrm{M}$ citric acid to a $\mathrm{pH}$ of 5.5 , before collection by SPE under low vacuum $(120 \mathrm{mmHg})$ at a flow rate $<5 \mathrm{~mL}$ per minute without drying. Samples were then rinsed with $5 \mathrm{~mL} 0.2 \mu \mathrm{m}$ filtered seawater and $5 \mathrm{~mL}$ Milli-Q water before being air dried under high vacuum $(360 \mathrm{mmHg})$. Samples were stored frozen until further processing at the landbased laboratory.

At the land-based laboratory, samples were brought to room temperature and prepared for HPLC purification and Gas Chromatography Mass Spectrometry (GCMS) analysis in the following way. Indophenol samples were eluted from SPE cartridges in $2 \mathrm{~mL}$ methanol. Samples were placed in a bench-top centrifuge for $2 \mathrm{~min}$ at $20000 \times \mathrm{G}$ to remove particulate material derived from the SPE column. A $500 \mu \mathrm{L}$ sub-sample was used for HPLC purification and GCMS analysis and the remaining $1.5 \mathrm{~mL}$ was stored at $-20^{\circ} \mathrm{C}$ for any subsequent repetition of the analysis. $500 \mu \mathrm{L}$ sub-samples were blown down under oxygen-free nitrogen (OFN) to $200 \mu \mathrm{L}$ for HPLC, during which it was absolutely essential that samples were not reduced to dryness, as this would result in significant sample loss. $175 \mu \mathrm{L}$ of the $200 \mu \mathrm{L}$ samples were purified by HPLC using the preparative system, mobile phases and profile described in Clark et al. (2006) in combination with a Gemini-NX 5u C18 110A $250 \times 4.6 \mathrm{~mm}$ column (Phenomenex, UK) and collecting sample fractions in a volume $<2 \mathrm{~mL}$. Collected sample fractions were blown dry under OFN at room temperature (alternative, faster procedures all resulted in sample loss, notably those that involved sample heating). Dried samples were stored for $24 \mathrm{~h}$ over anhydrous silica gel at room temperature prior to GCMS analysis. Samples were derivitised in $50 \mu \mathrm{L}$ of $5 \%$ Sylon HT in $n$-hexane and incubated at $50^{\circ} \mathrm{C}$ for $4 \mathrm{~h}$. Samples were analysed by GCMS using the system, ramping profiles and extracted ions described in Clark et al. (2006). Hexane (not alcohols) was used for GCMS syringe washes. Internal standards were used to quantify sample $\mathrm{NH}_{4}^{+}$concentration, and when combined with sample enrichment, the rate of $\mathrm{NH}_{4}^{+}$ regeneration was determined by applying the BlackburnCaperon model (Blackburn, 1979; Caperon et al., 1979).

SPE columns loaded with sudan-1 samples were brought to room temperature and processed for HPLC purification and GCMS analysis in the following way. Sudan-1 samples were eluted from SPE cartridges in $2 \mathrm{~mL}$ of ethyl acetate. $100-300 \mu \mathrm{L}$ sub-samples were used for further processing while the remaining samples were stored at $-20^{\circ} \mathrm{C}$ and available for subsequent repeated analysis. $100-300 \mu \mathrm{L}$ subsamples were blown dry under OFN, re-dissolved in $200 \mu \mathrm{L}$ methanol and centrifuged in a bench-top unit at $20000 \times \mathrm{G}$ for $2 \mathrm{~min}$ to remove particulate material derived from the SPE packing. Samples were transferred to GC vials and purified by HPLC. The HPLC system described in Clark et al. (2007) was used in combination with the Gemini column identified above and the mobile phase profile presented
Table 1. HPLC purification profile for sudan-1. Mobile phases were Milli-Q water and HPLC-grade methanol with a system flow rate of $1 \mathrm{~mL} \mathrm{~min}^{-1}$. Fraction collection took place in the range 25.5 $27.5 \mathrm{~min}$.

\begin{tabular}{ll}
\hline Time (min) & $\begin{array}{l}\% \text { methanol in } \\
\text { mobile phase }\end{array}$ \\
\hline 0 & 5 \\
5 & 5 \\
15 & 75 \\
20 & 100 \\
25 & 100 \\
30 & 5 \\
40 & 5 \\
\hline
\end{tabular}

in Table 1. Sample fractions, which were collected at retention time $25.5-27.5 \mathrm{~min}$, were dried using a Zymark Turbovap evaporation unit at $50^{\circ} \mathrm{C}$ using OFN. Dried samples were transferred to $\mathrm{GC}$ vials and stored over anhydrous silica gel for $24 \mathrm{~h}$ prior to derivitisation in a $50 \mu \mathrm{L}$ volume of $5 \%$ MTBSTFA in ethyl acetate at $70^{\circ} \mathrm{C}$ for $2 \mathrm{~h}$. The GCMS unit, ramping profile and extracted ions described in Clark et al. (2007) were used to derive sample $\mathrm{NO}_{2}^{-} / \mathrm{NO}_{3}^{-}$concentration and isotopic enrichment. The rate of $\mathrm{NH}_{4}^{+}$or $\mathrm{NO}_{2}^{-}$ oxidation was derived by re-arranging the mixing model of Sweeney et al. (1978) as described in Clark et al. (2007) and by applying the Blackburn-Caperon model (Blackburn, 1979; Caperon et al., 1979).

\subsection{Observational nitrogen assimilation measurements}

Using $6 \mathrm{~L}$ of seawater collected from the $55 \%$ sPAR depth, nitrogen assimilation rates were derived using ${ }^{15} \mathrm{~N}$ techniques. Triplicate $660 \mathrm{~mL}$ volumes of seawater were separately amended with ${ }^{15} \mathrm{NH}_{4}^{+},{ }^{15} \mathrm{NO}_{2}^{-}$and ${ }^{15} \mathrm{NO}_{3}^{-}$at an average enrichment of 7,18 and $20 \%$ of the ambient pool concentration respectively. Bottles were placed in deck incubators in conditions of simulated in situ light and temperature for an average of $6 \mathrm{~h}$. A volume of un-amended seawater was filtered through GF/F and used to derive the ${ }^{15} \mathrm{~N}$ natural abundance in particulate organic matter (PON). Deck incubations were terminated by filtration onto GF/F filters, which were frozen at $-20^{\circ} \mathrm{C}$ until isotope ratio mass spectrometry analysis was undertaken at the land-based laboratory. The rates of nitrogen assimilation $\left(\rho \mathrm{NH}_{4}^{+}, \rho \mathrm{NO}_{2}^{-}, \rho \mathrm{NO}_{3}^{-}\right)$ were determined using the equations of Dugdale and Goering (1967), corrected for nitrogen regeneration using the equations of Kanda et al. (1987).

\subsection{Observational $\mathrm{N}_{2} \mathrm{O}$ measurements}

Niskin bottles mounted to a stainless steel rosette were used to collect seawater from specific depths, which were transferred into $1 \mathrm{~L}$ borosilicate flasks using Tygon tubing. Samples were overfilled to three times bottle volume in 
order to expel trapped air bubbles, poisoned with $200 \mu \mathrm{L}$ of saturated $\mathrm{HgCl}$ solution and in all cases analysed within $8 \mathrm{~h}$ of collection. $\mathrm{N}_{2} \mathrm{O}$ concentration was determined by single-phase equilibration Gas Chromatography with Electron Capture Detection (GC-ECD) similar to that described by Upstill-Goddard et al. (1996). The analysis protocol involved determination of three certified $( \pm 2 \%)$ reference standards of 287, 402 and $511 \mathrm{ppb}$ (Air Products, UK) immediately before each sample with daily determination of the atmospheric mixing ratio against the same standards. Mean instrument precision from daily, triplicate analyses of the three calibration standards $(n=81)$ was $0.95 \%(\leq \pm 2.7 \%)$. The method returned gas partial pressures in the samples at equilibration temperature. Concentrations of in situ dissolved $\mathrm{N}_{2} \mathrm{O}$ were calculated from solubility tables of Weiss and Price (1980) at equilibration temperature (approximately $25^{\circ} \mathrm{C}$ ) and salinity. The per cent saturation of seawater with $\mathrm{N}_{2} \mathrm{O}$ was determined as the ratio of in situ $\mathrm{N}_{2} \mathrm{O}$ to atmospheric samples determined on-board (mean $322 \pm 7 \mathrm{ppb}$, cf. 322.8 at Mace Head, Ireland and 322.4 Ragged Point, Barbados).

\subsection{Ocean acidification bioassay (OAB) experiments}

Details of the $\mathrm{OAB}$ experiments, including implementation and aspects of interpretation are presented elsewhere (Richier et al., 2014a). As an overview, the carbonate chemistry of seawater collected from a depth of 5-12 $\mathrm{m}$ at five locations (identified as E1-5) in the NW European shelf sea was manipulated to provide three $P \mathrm{CO}_{2}$ treatments (550, $750,1000 \mu \mathrm{atm})$ and compared to an ambient treatment, in which carbonate chemistry was un-modified. A range of biological and chemical parameters were determined at the start of each OAB experiment, and again following $48\left(T_{48}\right)$ and $96\left(T_{96}\right) \mathrm{h}$ of incubation in order to assess the short-term response of the biological community to $\mathrm{PCO}_{2}$ treatments and the implications for seawater chemical composition. A stainless steel rosette to which were attached $24 \times 20 \mathrm{~L}$ Niskin bottles and CTD instrumentation was used to collect seawater in three successive casts at stations identified in Fig. 1. For the first two CTD casts, Niskin bottles were retrieved from the rosette as soon as access was permitted. Seawater was transferred in acid-cleaned silicon tubing into $72 \times 4.5 \mathrm{~L}$ polycarbonate incubation bottles, and distributed between the four separate treatments. In three treatments, the carbonate system was manipulated to achieve amended $P_{C O}$ targets of 550, 750, $1000 \mu$ atm by the addition of $\mathrm{NaHCO}_{3}^{-}+\mathrm{HCl}$ (Gattuso and Lavigne, 2009). Total alkalinity (TA) and DIC analysis (the remaining carbonate parameters were derived using CO2SYS) was immediately undertaken to verify these amendments after which bottles were sealed with septum lids, and incubated in a constanttemperature room equipped with LED-light banks. Samples were not pre-filtered to remove particles of any size prior to incubation; no information on particle density was available.
Incubation bottles were not rotated to avoid particle settling during these incubations as this would have been logistically impossible. Incubation temperature matched in situ conditions while an irradiance of $100 \mu \mathrm{E} \mathrm{m}^{-2} \mathrm{~s}^{-1}$ was provided in a $16 / 8 \mathrm{~h}$ light $/$ dark cycle for all OAB experiments. The third CTD cast was used for biogeochemical parameter determinations at the start of each $\mathrm{OAB}$ experiment (i.e. $T_{0}$ ). Biogeochemical parameter determinations were repeated at $T_{48}$ and $T_{96}$ time points by terminating selected bottle incubations.

\subsection{Statistical analysis of observational and bioassay data}

Data generated during this study in combination with that of other cruise participants (Richier et al., 2014b) were analysed in a multivariate context using PRIMER v6 (Clarke and Gorley, 2006) and PERMANOVA+ (Anderson et al., 2008). The former utilises a robust non-parametric multivariate analytical approach, while the latter extends some of the ideas underpinning PRIMER to allow analyses of higher-way experimental designs. At each of the five OAB locations, samples were collected and analysed from four different experimental treatments (Ambient, 550, 750, $1000 \mu \mathrm{atm}$ ) at two time points $\left(T_{48}\right.$ and $\left.T_{96} \mathrm{~h}\right)$. Additional samples analysed from the commencement of experiments (i.e. $T_{0}$ ) represented the initial (ambient) conditions. Thus there were 45 combinations of treatment and time, in an unbalanced design. Although efforts were made to replicate measurements within combinations of experimental treatments, these were made with a view to replicating measurements of individual variables rather than producing genuine replicates representative of the true variability across variables within the overall experimental set-up. Thus experimental units were not sampled to provide matching variability estimates for all variables, but different measurements were made on different units. The experiments were not "fully replicated" in a multivariate context. To analyse the data in a multivariate context it was therefore necessary to pool (average) measurements of each variable within experimental treatments.

An additional complication was that many variables were not measured in all 45 combinations of experimental treatments. This was particularly so in $T_{0}$ treatments. Omitting these samples from the analysis left one missing pool observation from location 3 at $T_{96}$. This was $\mathrm{NH}_{4}^{+}$regeneration rate in the $1000 \mu$ atm treatment. Rather than removing this variable from further analyses, a value for this observation was estimated using the EM (estimation maximisation) algorithm (Clarke and Gorley, 2006). The data set, on which the following analysis was based, therefore consisted of $40 \mathrm{com}-$ binations of experimental treatments (four $P \mathrm{CO}_{2}$ treatments measured at two times and at five locations).

Of the variables recorded, some were "explanatory", being those that represented experimental conditions (manipulated or otherwise). These included physical measures such as temperature and salinity which were not measured in each 
experimental unit, but were recorded as a single value for each location. Others, the "response" variables, represented potential variation in response to variation in the explanatory variables. These could be grouped into a range of types identified in Table 2 which included measurements of inorganic nutrient concentration, carbonate parameters and microbial populations from analytical flow-cytometry. The first, and most obvious, question to address was whether there were differences in values of response variables among levels of experimental treatments. Only if this was the case did it make sense to go on to try and relate these to measurements of explanatory variables.

Variables were normalised to convert them to a common scale by subtracting the mean and dividing by the standard deviation. For all variables, and separately for each of the groups of variables, a Euclidean distance matrix of differences between every pair of samples was calculated and used to conduct tests of differences between locations (LO), treatments (TR) and times (TI), using permutation-based analysis of variance (Anderson, 2001; McArdle and Anderson, 2001). This procedure is formally equivalent to a standard ANOVA but the flexibility and robustness of the permutation approach ameliorates the necessity for variables to fulfil standard assumptions, such as normality. Tests were carried out for all variables, and for each of the variable groups.

\section{Results}

Macro-scale features of the NW European shelf sea area are presented in 7-day composite Earth observation images for sea-surface temperature (EO-SST), chlorophyll (EO-Chl) and enhanced colour (EO-EC, which provides a qualitative indication of coccolith density; Fig. 2). During this investigation sea-surface temperature of the shelf sea region generally increased, with warmer water being evident progressively further north. EO-Chl data suggested a regional-scale proliferation of autotrophic growth from approximately 10 June which persisted in coastal regions beyond the end of this study period, notably within the southern North Sea, Skagerrak and Norwegian Current areas. Enhanced colour imagery was used to further discriminate the characteristics of shelf sea water masses: seawater free of particulate matter (i.e. phytoplankton cells or sediments) appears blue; plankton blooms appear green or brown-red for more dense blooms; suspended sediment appears white/yellow; coccolith blooms appear brighter turquoise. A region of relatively high coccolith concentration in the central North Sea was prominent from 4 June and remained discernible for 4 weeks.

Contour plots of water column temperature, chlorophyll, inorganic nutrients $\left(\mathrm{NO}_{2 / 3}^{-}, \mathrm{PO}_{4}^{3-}\right)$ and $\mathrm{N}_{2} \mathrm{O}$ concentration are presented in Fig. 3 and summarised below. Water column profiles for western Scotland suggested that the upper $80 \mathrm{~m}$ were relatively cool and mixed. For western Ireland and the Celtic Sea, the water column was stratified with an up-
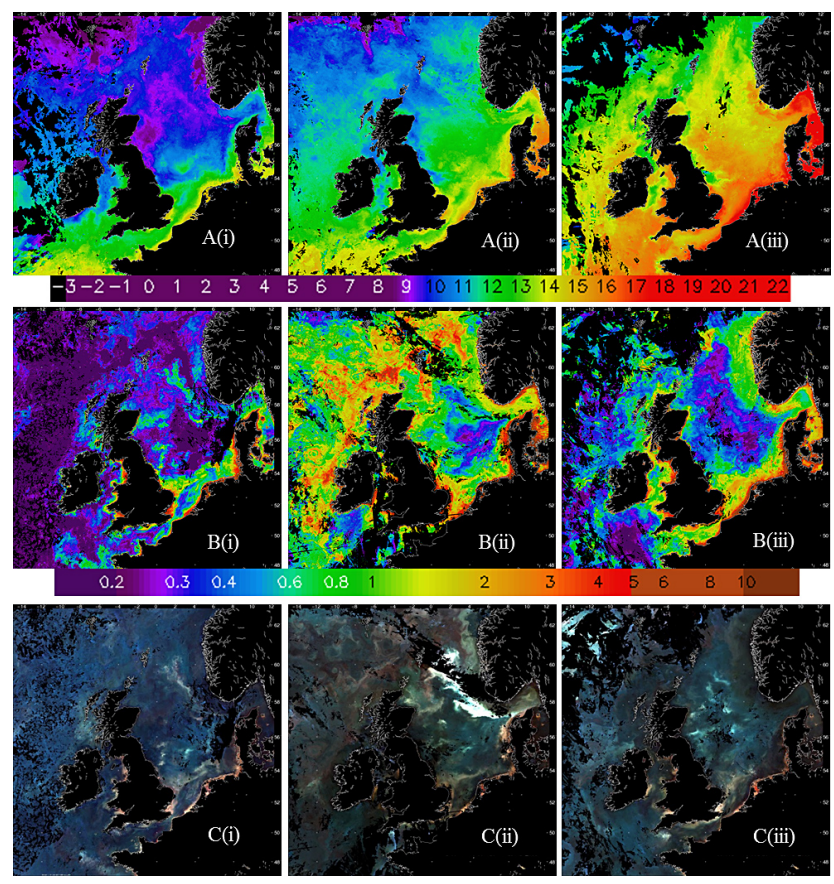

Figure 2. Earth observation 7-day composite images of sea-surface temperature $\left(\mathbf{a}^{\circ} \mathrm{C}\right)$, chlorophyll concentration $\left(\mathbf{b} \mathrm{mg} \mathrm{m}^{-3}\right)$ and enhanced-colour (c) starting from Julian days 146 (26 May (i)), 163 (12 June (ii)) and 190 (9 July (iii)).

per mixed layer depth of approximately $40 \mathrm{~m}$. The highest water column temperatures were associated with the Biscay region, which were mixed to depths exceeding $80 \mathrm{~m}$. As the ship re-entered the English Channel and proceeded through the North Sea, strong water column stratification was evident, with an upper mixed layer depth of $10 \mathrm{~m}$ in the southern North Sea, increasing to approximately $25 \mathrm{~m}$ in the northern North Sea and $40 \mathrm{~m}$ in the North Atlantic off the Scottish north coast.

Chlorophyll profiles suggested a patchy autotroph distribution. Relatively high chlorophyll concentrations were associated with the well mixed water of western Scotland, coinciding with relatively high nutrient availability for both $\mathrm{NO}_{2 / 3}^{-}$and $\mathrm{PO}_{4}^{3-}$. Nutrient concentrations in the upper $40 \mathrm{~m}$ of the Celtic Sea, Biscay and southern North Sea regions were low in $\mathrm{PO}_{4}^{3-}$, occasionally coinciding with relatively low $\mathrm{NO}_{2 / 3}^{-}$. A high concentration of chlorophyll was identified as a discrete feature at approximately $30 \mathrm{~m}$ in a region of the northern North Sea where cooler waters with higher nutrient concentrations were located at relatively shallow depths. This feature was associated with a coccolithophorid bloom. Progressing through the North Sea and into the North Atlantic relatively high chlorophyll concentrations were again observed in the upper mixed layer, associated with high inorganic nutrient concentrations.

The range of $\mathrm{N}_{2} \mathrm{O}$ concentrations for all profiles was narrow (approximately $8-12 \mathrm{nmol} \mathrm{L}^{-1}$ ). Relatively high $\mathrm{N}_{2} \mathrm{O}$ 
Table 2. Identification of parameters arranged within groups for statistical analysis of bioassay and observational data.

\begin{tabular}{|c|c|}
\hline Group identifier & Parameters included within group \\
\hline Physical & $\begin{array}{l}\text { Salinity } \\
\text { Temperature }\end{array}$ \\
\hline Carbonate & $\begin{array}{l}\text { Total alkalinity } \\
\text { Dissolved inorganic carbon } \\
{\left[\mathrm{HCO}_{3}^{-}\right] \text {(calculated from DIC and TA using CO2SYS) }} \\
{\left[\mathrm{CO}_{3}^{2-}\right] \text { (calculated from DIC and TA using CO2SYS) }} \\
\mathrm{PCO}_{2} \text { (calculated from DIC and TA using CO2SYS) } \\
\Omega \mathrm{ca} \text { (calculated from DIC and TA using CO2SYS) } \\
\Omega \text { ar (calculated from DIC and TA using CO2SYS) } \\
\text { pH (calculated from DIC and TA using CO2SYS) }\end{array}$ \\
\hline Inorganic nutrient & $\begin{array}{l}{\left[\mathrm{NO}_{3}^{-}\right]} \\
{\left[\mathrm{NO}_{2}^{-}\right]} \\
{\left[\mathrm{Si}(\mathrm{OH})_{4}\right]} \\
{\left[\mathrm{PO}_{4}^{2-}\right]} \\
{\left[\mathrm{NH}_{4}^{+}\right]} \\
{\left[\mathrm{O}_{2}\right]} \\
\text { Dimethylsulfide (DMS) } \\
\text { Total dimethylsulfoniopropionate (TDMSP) }\end{array}$ \\
\hline Organic nutrient & $\begin{array}{l}\text { Dissolved organic carbon } \\
\text { Total dissolved nitrogen } \\
\text { Transparent exopolymer particles } \\
\text { Biogenic silica }\end{array}$ \\
\hline Phytoplankton & $\begin{array}{l}\text { Total and size fractionated chlorophyll a } \\
\text { Fast repetition rate (FRR) calibrated fluorescence } \\
\text { Maximum photochemical yield of photosystem II (photosynthetic efficiency) } \\
\text { Effective absorption cross section in darkness } \\
\text { Minimum turnover time of PSII photochemistry } \\
\text { Primary production } \\
\text { Calcite production } \\
\text { Coccolithophore cell density } \\
\text { Emiliania huxleyi coccospheres counted }\end{array}$ \\
\hline Particulate & $\begin{array}{l}\text { Particulate organic carbon/nitrogen/phosphorous } \\
\text { Particulate dimethylsulfoniopropionate }\end{array}$ \\
\hline $\begin{array}{l}\text { Analytical flow } \\
\text { cytometry }\end{array}$ & $\begin{array}{l}\text { High / low nucleic acid bacteria } \\
\text { Total bacteria } \\
\text { Synechococcus cell density } \\
\text { Heterotrophic Nanoflagellates abundance } \\
\text { Phototrophic nano/picoplankton abundance }\end{array}$ \\
\hline Nitrogen cycling & $\begin{array}{l}\mathrm{NH}_{4}^{+} \text {regeneration rate } \\
\mathrm{NH}_{4}^{+} \text {oxidation rate } \\
\mathrm{NO}_{2}^{-} \text {oxidation* } \\
\mathrm{NH}_{4}^{+} / \mathrm{NO}_{2}^{-} / \mathrm{NO}_{3}^{-} \text {assimilation rate* } \\
{\left[\mathrm{N}_{2} \mathrm{O}\right]} \\
{\left[\mathrm{CH}_{4}\right]}\end{array}$ \\
\hline
\end{tabular}

\footnotetext{
* Parameter included in the analysis of observational data only.
} 

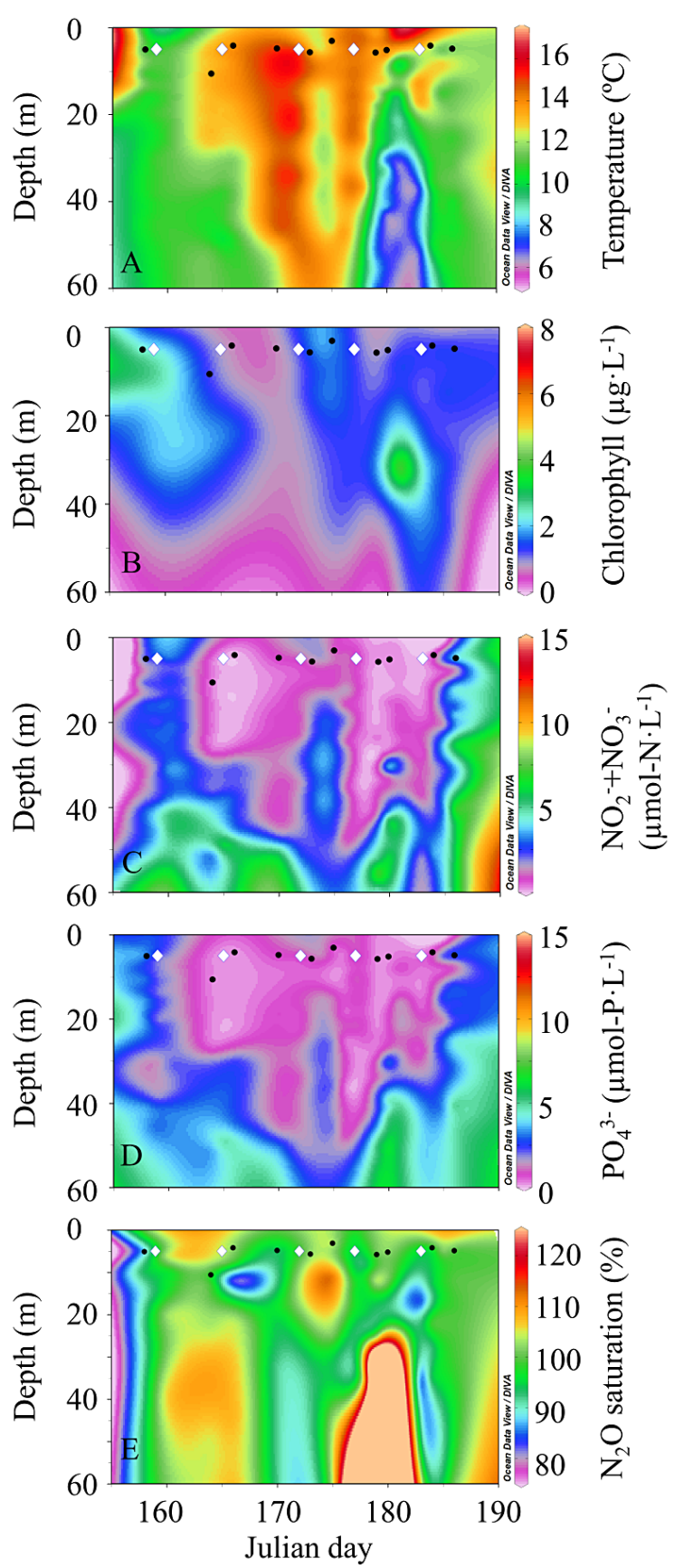

Figure 3. Contour plots of temperature (a), chlorophyll (b), $\mathrm{NO}_{3}^{-}+\mathrm{NO}_{2}^{-}$(c), $\mathrm{PO}_{4}^{3-}$ (d) and $\mathrm{N}_{2} \mathrm{O}$ saturation (e) derived during the cruise track. The position (Julian day and sample depth) of observational and bioassay stations is indicated by black circles and white diamonds (sequentially E1-E5) respectively.

concentrations were associated with the cool, mixed, high chlorophyll, high nutrient waters of western Scotland. Concentrations decreased through the Celtic Sea, Western Approaches and into the Biscay region. $\mathrm{N}_{2} \mathrm{O}$ concentrations remained relatively low in the surface stratified water of the North Sea, although higher concentrations were measured

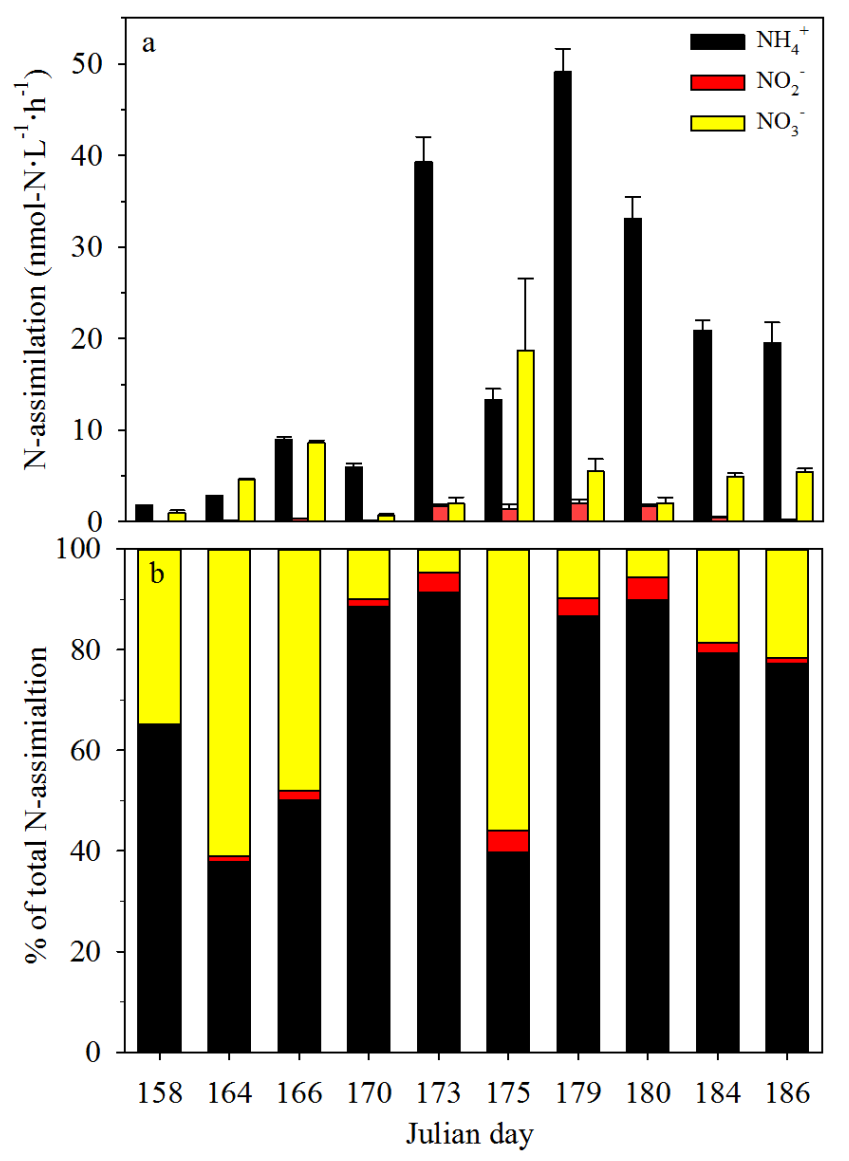

Figure 4. The rate of $\mathrm{NH}_{4}^{+}, \mathrm{NO}_{2}^{-}$and $\mathrm{NO}_{3}^{-}$assimilation (a) determined at observational stations identified in Fig. 1, and the contribution (in \%) that each inorganic nitrogen source makes to total $\mathrm{N}$-assimilation (b).

below the upper mixed layer. A loose association between higher $\mathrm{N}_{2} \mathrm{O}$ concentration and lower temperature was apparent in profile data, possibly related to increased gas solubility.

The rate of $\mathrm{NH}_{4}^{+}, \mathrm{NO}_{2}^{-}$and $\mathrm{NO}_{3}^{-}$assimilation is presented in Fig. 4 and includes the contribution of each to the combined rate of nitrogen assimilation (i.e. $\mathrm{NH}_{4}^{+}$assimilation $+\mathrm{NO}_{2}^{-}$assimilation $+\mathrm{NO}_{3}^{-}$assimilation), which ranged from 3 to $57 \mathrm{nmolNL}^{-1} \mathrm{~h}^{-1}$. The lowest combined rates of nitrogen assimilation $\left(<18 \mathrm{nmol} \mathrm{N} \mathrm{L}^{-1} \mathrm{~h}^{-1}\right)$ were associated with western Scotland, Celtic Sea, western English Channel (time series Station E1; first visit) and Biscay regions. Following the passage of a storm in the Western Approaches region, higher rates were associated with stations in the Western Approaches and the western English Channel station E1 (33-43 nmol N L $\left.{ }^{-1} \mathrm{~h}^{-1}\right)$. Combined rates of 25-57 nmol N L$~_{-1} \mathrm{~h}^{-1}$ were measured at the remaining stations in the North Sea and North Atlantic. $\mathrm{NH}_{4}^{+}$assimilation frequently dominated phytoplankton nitrogen demand while $\mathrm{NO}_{2}^{-}$assimilation made a variable contribution $(0-5 \%)$. 

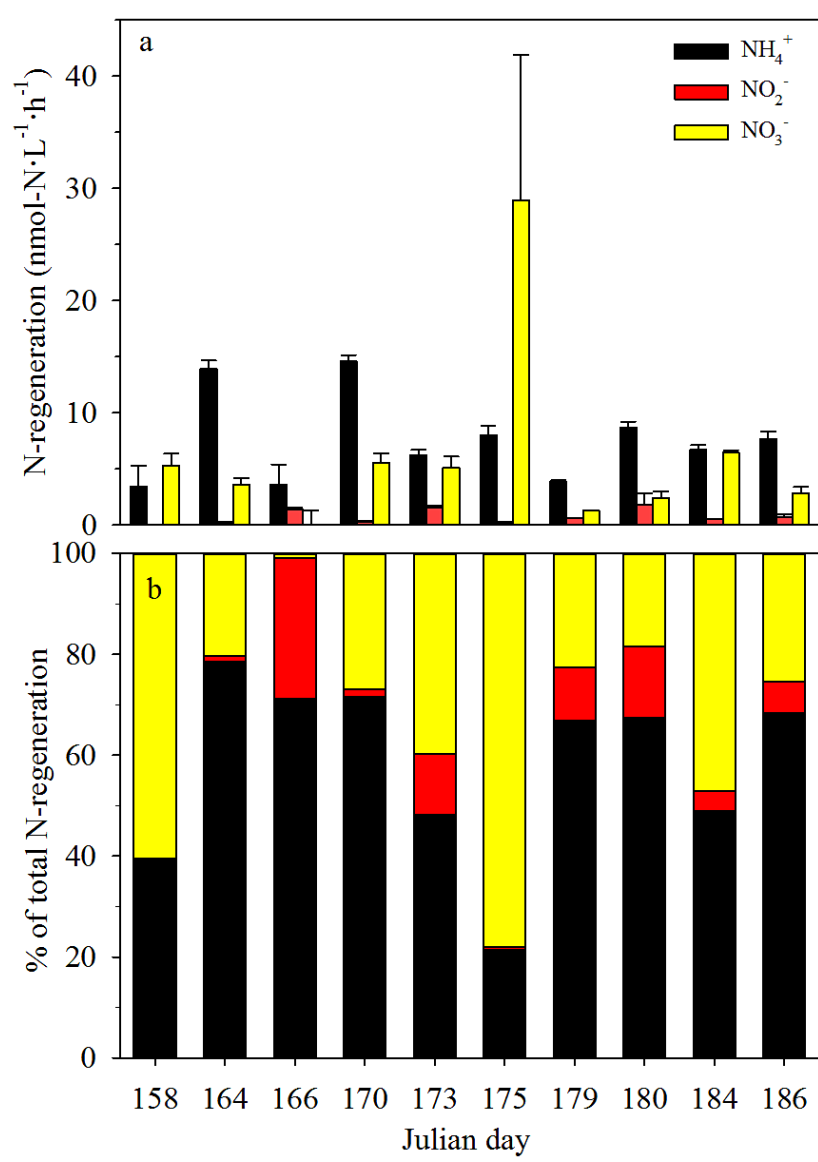

Figure 5. The rate of $\mathrm{NH}_{4}^{+}, \mathrm{NO}_{2}^{-}$and $\mathrm{NO}_{3}^{-}$regeneration (a) determined at observational stations identified in Fig. 1, and the contribution (in \%) that each inorganic nitrogen source makes to total $\mathrm{N}$-regeneration (b).

The rate of $\mathrm{NH}_{4}^{+}$regeneration, $\mathrm{NH}_{4}^{+}$oxidation and $\mathrm{NO}_{2}^{-}$ oxidation is presented in Fig. 5. Nitrogen regeneration process rates were detectable at all stations, with a combined rate (i.e. $\mathrm{NH}_{4}^{+}$regeneration $+\mathrm{NH}_{4}^{+}$oxidation $+\mathrm{NO}_{2}^{-}$oxidation) of 5-37 nmol N L ${ }^{-1} \mathrm{~h}^{-1}$. $\mathrm{NH}_{4}^{+}$regeneration frequently made the largest contribution to the combined rate, while the separate stages of nitrification were frequently uncoupled at the sampling depth investigated (average ratio of 0.22 for $\mathrm{NH}_{4}^{+}: \mathrm{NO}_{2}^{-}$oxidation). A very high rate of $\mathrm{NO}_{2}^{-}$oxidation measured at station E1 (Julian day 175) following the passage of a storm was a prominent feature of these results.

Selected OAB data are presented in Figs. 8 and 9. As an indication of potential microbial community responses to $\mathrm{PCO}_{2}$ treatment, the abundance of bacterial cells and heterotrophic nanoflagellates are presented as these were anticipated to be most closely associated with the processes of $\mathrm{NH}_{4}^{+}$regeneration and oxidation. Further details of changes in carbonate chemistry and inorganic nutrients during bioassay experiments are presented by Richier et al. (2014a). Box plots collated data from up to nine replicate bottles per treatment and time point. Across all bioassay experiments, $P \mathrm{CO}_{2}$ initial conditions were $364 \pm 21 \mu \mathrm{atm}, 538 \pm 13 \mu \mathrm{atm}$, $710 \pm 29 \mu \mathrm{atm}$ and $912 \pm 38 \mu \mathrm{atm}$ for ambient, 550, 750 and $1000 \mu \mathrm{atm}$ treatments respectively. Corresponding initial $\mathrm{pH}$ values were $8.08 \pm 0.02,7.94 \pm 0.01,7.83 \pm 0.02$, $7.73 \pm 0.02$ respectively. During the progression of experiments, $\mathrm{pH} / \mathrm{PCO}_{2}$ changed in a way which was inconsistent between bioassays. Similarly, microbial community abundance differed between geographical locations and changed in a way which was frequently inconsistent between bioassay experiments. The concentration of $\mathrm{N}_{2} \mathrm{O}$ and the rates of $\mathrm{NH}_{4}^{+}$ regeneration and $\mathrm{NH}_{4}^{+}$oxidation are presented in Fig. 9. Cursory examination suggested that $\mathrm{NH}_{4}^{+}$regeneration rate increased with $\mathrm{PCO}_{2}$ at E1 and E3. However, no consistent response between bioassays was immediately evident. Independent measurements of nitrification activity, namely the rate of $\mathrm{NH}_{4}^{+}$oxidation and changes in $\mathrm{N}_{2} \mathrm{O}$ concentration (a product of the $\mathrm{NH}_{4}^{+}$oxidation process) suggested that there were no clear treatment-related responses between time points and locations.

Statistical analysis of observational data, which included all available biogeochemical data from cruise participants, was undertaken in an attempt to identify links between nitrogen cycle process rates and environmental variables (Table 2). Excluding variables with missing observations from one or more sites, a suite of 27 variables were retained. A "Similarity Profile" analysis (SIMPROF; Clarke et al., 2008) based on normalised Euclidean distances among samples calculated from 10 explanatory variables ("physical" and "carbonate" parameters) indicated significant multivariate structure $(\mathrm{Pi}=1.62, p<0.001)$, but a similar analysis based on 17 response variables ("inorganic nutrient" parameters excluding [DMSP], "nitrogen cycle" parameters excluding $\left[\mathrm{CH}_{4}\right]$, total chlorophyll, dissolved organic carbon, total nitrogen) indicated that there was no structure to interpret $(\mathrm{Pi}=0.238$, $p=0.115)$. A further SIMPROF analysis based on correlations among response variables reinforced this, failing to reject the null of "no significant correlation" $(\mathrm{Pi}=0.234, p=$ 0.106). A BIOENV analysis was undertaken, which searches for subsets of variables that, in combination, "best match" a pattern defined by a target resemblance matrix. The match was quantified using a Spearman rank correlation between corresponding elements in the resemblance matrices. Owing to the lack of independence among elements in such matrices and a selection bias explicit in the method, standard methods for testing the significance of these correlations were invalid. Consequently, a permutational procedure was adopted (Clarke et al., 2008). Using a normalised Euclidean distance resemblance matrix derived from all 10 explanatory variables, a search through all subsets of response variables (up to subsets with a maximum of 10 variables) found a highest rank correlation of 0.84 , with a combination consisting of $\mathrm{NO}_{2}^{-}, \mathrm{Si}\left(\mathrm{OH}_{4}\right), \mathrm{NH}_{4}^{+}$, DOC and total dissolved nitrogen. Despite the apparent strength of this relationship, a permutation 
Table 3. Summary of results from permutation-based analysis of variance tests for differences among parameter groups using Type III sums of squares based on 999 permutations of residuals under a reduced model. Details of the parameters included in parameter groups are provided in Table 2. Location (Lo) was included as a random factor, while treatment (Tr) and time (Ti) were fixed.

\begin{tabular}{|c|c|c|c|c|c|c|c|c|c|c|c|c|c|c|c|}
\hline \multirow[b]{2}{*}{ Source } & \multirow[b]{2}{*}{$\mathrm{d} f$} & \multicolumn{2}{|c|}{ All } & \multicolumn{2}{|c|}{ Inorganic nutrients } & \multicolumn{2}{|c|}{ Organic nutrients } & \multicolumn{2}{|c|}{ Phytoplankton } & \multicolumn{2}{|c|}{ Particulate } & \multicolumn{2}{|c|}{ Analytical flow cytometry } & \multicolumn{2}{|c|}{ Nitrogen cycling } \\
\hline & & Pseudo- $f$ & $p$ & Pseudo- $f$ & $p$ & Pseudo- $f$ & $p$ & Pseudo- $f$ & $p$ & Pseudo- $f$ & $p$ & Pseudo- $f$ & $p$ & Pseudo- $f$ & $p$ \\
\hline Lo & 4 & 25.64 & 0.00 & 44.15 & 0.00 & 18.96 & 0.00 & 36.93 & 0.00 & 65.04 & 0.00 & 13.24 & 0.00 & 13.87 & 0.00 \\
\hline $\operatorname{Tr}$ & 3 & 2.65 & 0.00 & 4.98 & 0.00 & 0.58 & 0.82 & 2.20 & 0.02 & 4.12 & 0.01 & 3.93 & 0.00 & 1.68 & 0.10 \\
\hline $\mathrm{Ti}$ & 1 & 2.41 & 0.06 & 2.05 & 0.19 & 8.85 & 0.01 & 1.39 & 0.32 & 5.94 & 0.05 & 1.99 & 0.22 & 1.12 & 0.47 \\
\hline $\mathrm{Lo} \times \mathrm{Tr}$ & 12 & 1.33 & 0.04 & 1.62 & 0.04 & 1.23 & 0.28 & 1.83 & 0.01 & 0.99 & 0.53 & 1.00 & 0.54 & 1.28 & 0.23 \\
\hline $\mathrm{Lo} \times \mathrm{Ti}$ & 4 & 3.86 & 0.00 & 12.14 & 0.00 & 1.72 & 0.11 & 4.11 & 0.00 & 2.36 & 0.03 & 3.64 & 0.00 & 1.94 & 0.06 \\
\hline $\mathrm{Tr} \times \mathrm{Ti}$ & 3 & 1.98 & 0.03 & 2.47 & 0.03 & 2.47 & 0.03 & 2.58 & 0.02 & 0.96 & 0.46 & 2.10 & 0.06 & 0.94 & 0.53 \\
\hline
\end{tabular}

test demonstrated that values of 0.84 or greater occurred $11 \%$ of the time purely by chance. The equivalent results for a test using only the carbonate variables (Table 2 ) returned a maximum correlation of 0.78 (with variables $\mathrm{NO}_{2}^{-}, \mathrm{Si}\left(\mathrm{OH}_{4}\right)$, $\mathrm{NH}_{4}^{+}$, DOC and total dissolved nitrogen) but values as high or higher than this occurred $28 \%$ of the time in random rearrangements of the data. With $\mathrm{pH}$ alone the highest correlation $(0.8)$ was with a single variable $\left(\mathrm{PO}_{4}^{3-}\right)$ and the second highest match (0.77) was with a subset of five variables $\left(\mathrm{NO}_{2}^{-}\right.$, $\mathrm{Si}(\mathrm{OH})_{4}, \mathrm{PO}_{4}^{3-}, \mathrm{O}_{2}$ and $\mathrm{NH}_{4}^{+}$assimilation rate), but values of 0.8 or higher occurred $16 \%$ of the time in random permutations. Thus none of these relationships could be considered significant.

Statistical analysis was extended to bioassay data, considering stations both individually and collectively, in order to provide a rigorous and impartial interrogation. The aims were to (i) identify significant treatment effects in the bioassay data set so that (ii) any significant treatment effects in relation to nitrogen cycle processes could be placed into context. Results of this analysis are presented in Table 3. For all groups of variables there were significant differences among groups of samples. However, although there were apparent significant treatment effects, it should be noted that the majority of interactions among factors were also significant $(p<0.05)$. Consequently, there was little evidence of consistent effects of treatment or time across the five locations. Ignoring these, significant differences among levels of treatment (Table 4) tended to be between ambient treatments and high $\mathrm{PCO}_{2}$, and for most groups of variables there was no evidence of differences among manipulated treatments. However, there was evidence for significant treatment effects related to inorganic nutrients (Fig. 10). These results indicated that the normalised concentration of specific inorganic nutrients $\left(\mathrm{PO}_{4}^{3+}, \mathrm{NO}_{2 / 3}^{-}, \mathrm{NH}_{4}^{+}\right)$and DMS increased with $\mathrm{PCO}_{2}$ treatment while that of TDMSP decreased. The normalised concentration of silicate $\left(\mathrm{Si}(\mathrm{OH})_{4}\right)$ was unchanged, implying that diatoms had no short-term role in this relation.

Examining estimates of components of variation (summarised as ranks in Table 5) demonstrated that most of the variation was associated with differences among locations, followed by residual variation not associated with the terms in the ANOVA model. Little variability was explained by differences between times, and the least important sources of variation were those associated with differences among treatments. This pattern was consistent, with minor variation, across all groups of variables. Relationships among samples (and groups of samples) could be visualised by an appropriate ordination (Fig. 11). The differences among samples from different locations were readily apparent; differences among treatments or between times less so. Water column characteristics may have contributed to the clustering of results for $\mathrm{E} 2+4$ and $\mathrm{E} 3+5$, being sampled from a fully mixed or stratified water column respectively. The distinct clustering of E1 data, which was sampled from a stratified water column, may have related to bioassay bottle conditioning effects (Richier et al., 2014a).

\section{Discussion}

During this study a ship-based bioassay approach was used to investigate the response of surface ocean microbial communities to projected ocean acidification conditions. This approach had the major advantage that different geographical locations could be examined and compared to observations. Earth observation data demonstrated that $\mathrm{OAB}$ experiments were conducted in contrasting areas which was reflected in the biogeochemical composition of seawater sampled. Through observational data we demonstrated that microbial nitrogen regeneration and assimilation took place within the near-surface ocean at all locations and that the range of nitrogen regeneration rates was comparable between observational and bioassay experiments. We undertook statistical analysis in an attempt to uncover a mechanistic basis for our observations and to place nitrogen cycle OA treatment responses into context. We found that the biological response to $\mathrm{PCO}_{2}$ treatments differed between locations and that a mechanistic understanding of how nitrogen cycle processes responded to OA could not be achieved.

\subsection{Observational measurements of the nitrogen cycle}

Considering all stations, total nitrogen assimilation rate (i.e. $\mathrm{NH}_{4}^{+}+\mathrm{NO}_{2}^{-}+\mathrm{NO}_{3}^{-}$) ranged from 2.8 to $56.7 \mathrm{nmol} \mathrm{N} \mathrm{L}^{-1} \mathrm{~h}^{-1}$ 
Table 4. Summary of results from pairwise tests for differences among levels of treatment, from permutation-based analysis of variance tests for differences among groups using Type 1 sums of squares based on 999 permutations of residuals under a reduced model. Details of the parameters included in parameter groups are provided in Table 2.

\begin{tabular}{llllllll}
\hline Groups & All & Inorganic nutrients & Organic nutrients & Phytoplankton & Particulate & Analytical flow cytometry & Nitrogen cycling \\
\hline Ambient, 550 & n.s. & n.s. & n.s. & n.s. & n.s. & $*$ & n.s. \\
Ambient, 750 & $*$ & $*$ & n.s. & n.s. & $*$ & $*$ & n.s. \\
Ambient, 1000 & $*$ & $*$ & n.s. & n.s. & n.s. & n.s. & n.s. \\
550,750 & n.s. & $*$ & n.s. & n.s. & n.s. & n.s. \\
550,1000 & n.s. & $*$ & n.s. & n.s. & n.s. & n.s. \\
750,1000 & n.s. & $*$ & n.s. & $*$ & n.s. & \\
\hline
\end{tabular}

Note: $*=p<0.05$, n.s. $=p>0.05$.

Table 5. Ranked estimates of components of variation for permutation-based analysis of variance tests. Details of the parameters included in parameter groups are provided in Table 2. Lo - location, $\mathrm{Tr}$ - treatment, Ti - time, Res - residual. "Average" indicates the average rank across groups of variables excluding the ranks for all variables.

\begin{tabular}{lllllllll}
\hline Source & All & $\begin{array}{l}\text { Inorganic } \\
\text { nutrients }\end{array}$ & $\begin{array}{l}\text { Organic } \\
\text { nutrients }\end{array}$ & Phytoplankton & $\begin{array}{l}\text { Particulates } \\
\text { flow cytometry }\end{array}$ & $\begin{array}{l}\text { Analytical } \\
\text { cycling }\end{array}$ & Nitrogen & Average \\
\hline $\mathrm{V}(\mathrm{Lo})$ & 1 & 1 & 1 & 1 & 1 & 1 & 1 & 1.0 \\
$\mathrm{~S}(\mathrm{Tr})$ & 5 & 5 & 7 & 6 & 5 & 4 & 6 & 5.5 \\
$\mathrm{~S}(\mathrm{Ti})$ & 4 & 4 & 3 & 7 & 3 & 6 & 3 & 4.3 \\
$\mathrm{~V}(\mathrm{Lo} \times \mathrm{Tr})$ & 7 & 6 & 6 & 4 & 7 & 7 & 5 & 5.8 \\
$\mathrm{~V}(\mathrm{Lo} \times \mathrm{Ti})$ & 3 & 2 & 5 & 3 & 4 & 5 & 4 & 3.5 \\
$\mathrm{~S}(\mathrm{Tr} \times \mathrm{Ti})$ & 6 & 7 & 4 & 5 & 7 & 2 & 2 & 5.8 \\
$\mathrm{~V}(\operatorname{Res})$ & 2 & 3 & 2 & 2 & 2 & & 2.2 \\
\hline
\end{tabular}

(Fig. 4). $\mathrm{NH}_{4}^{+}$assimilation ranged 27 -fold, $\mathrm{NO}_{2}^{-}$assimilation ranged 262-fold and $\mathrm{NO}_{3}^{-}$assimilation ranged 28-fold. Nitrogen assimilation rates were comparable to previous observations in the North Sea (Reigman and Noordeloos, 1998; Rees et al., 2002; Weston et al., 2004) and indicated that phytoplankton preferentially assimilated $\mathrm{NH}_{4}^{+}$during the summer months. In contrast to the range of nitrogen assimilation rates measured, PON varied only 1.6 fold (range 1.0$1.7 \mu \mathrm{mol} \mathrm{N} \mathrm{L}{ }^{-1}$ ). While this plasticity could relate to changes in the ability of phytoplankton to utilise inorganic nitrogen, it was more likely to reflect changes in phytoplankton composition between stations, although we lacked taxonomic data to verify this.

Determinations of nitrogen assimilation rates for three inorganic forms were made simultaneously and indicated that the phytoplankton community maintained the ability to utilise all three nitrogen sources concurrently, although not implying that a single species was able to achieve this. It is curious that the near sea-surface community maintained a capacity to assimilate $\mathrm{NO}_{2}^{-}$given that this nitrogen source represented a minor fraction of the total DIN pool. The phytoplankton community at the depth sampled $(<10 \mathrm{~m})$ were unlikely to encounter high $\mathrm{NO}_{2}^{-}$concentrations such as those associated with a primary $\mathrm{NO}_{2}^{-}$maximum (Lomas and Lipschultz, 2006). However, it is feasible that episodic events such as storm-induced mixing could lead to transient uncoupling between $\mathrm{NO}_{2}^{-}$source and sink processes leading to localised short-term increases in $\mathrm{NO}_{2}^{-}$concentration; maintaining an opportunistic ability to utilise pulses of $\mathrm{NO}_{2}^{-}$ may have been advantageous. In support of this, Wafar et al. (2004) demonstrated that during an annual cycle in a permanently well-mixed water column in the English Channel, phytoplankton were able to assimilate $\mathrm{NO}_{2}^{-}$at a rate which was comparable to, though less than that of urea.

Data from observational stations emphasised the importance of regenerated productivity despite the low ambient $\mathrm{NH}_{4}^{+}$concentration observed (average $342 \mathrm{nmol} \mathrm{NL}^{-1}$, range $120-795 \mathrm{nmol} \mathrm{NL}^{-1}$ ). The significance of $\mathrm{NH}_{4}^{+}$cycling for the shelf sea region has been noted in previous studies over a wider geographical area (Kühn and Radach, 1997; Reigman and Noordeloos, 1998; Rees et al., 2002; Weston et al., 2004) and across seasons (Maguer et al., 1999; 2011; Wafar et al., 2004) and may have had particular prominence during the summer months of this study when nitrogen availability could limit phytoplankton productivity (Van Engeland et al., 2010). The ratio between $\mathrm{N}$-regeneration processes (i.e. $\mathrm{NH}_{4}^{+}$regeneration : $\mathrm{NH}_{4}^{+}$oxidation: $\mathrm{NO}_{2}^{-}$oxidation), $\mathrm{N}$-assimilation processes $\left(\mathrm{NH}_{4}^{+}\right.$assimilation : $\mathrm{NO}_{2}^{-}$assimilation: $\mathrm{NO}_{3}^{-}$assimilation) and DIN availability $\left(\left[\mathrm{NH}_{4}^{+}\right]:\left[\mathrm{NO}_{2}^{-}\right]:\left[\mathrm{NO}_{3}^{-}\right]\right)$was comparable (Fig. 6), implying relatively close coupling between regeneration and assimilation processes at the regional 


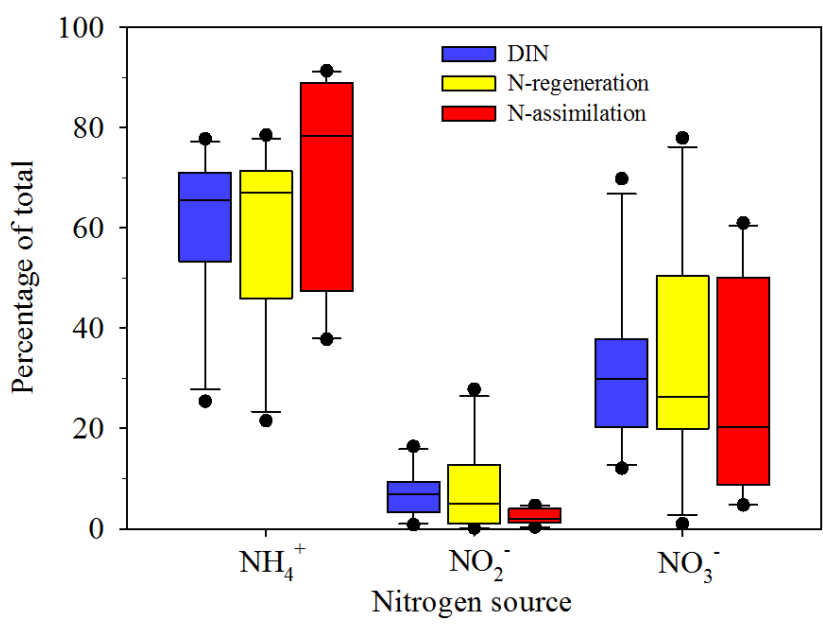

Figure 6. Ratio between dissolved inorganic nitrogen (DIN) availability $\left(\mathrm{NH}_{4}^{+}: \mathrm{NO}_{2}^{-}: \mathrm{NO}_{3}^{-}\right)$, inorganic nitrogen regeneration rate $\left(\mathrm{NH}_{4}^{+}\right.$regeneration : $\mathrm{NH}_{4}^{+}$oxidation: $\mathrm{NO}_{2}^{-}$oxidation) and inorganic nitrogen assimilation rate $\left(\mathrm{NH}_{4}^{+}\right.$assimilation : $\mathrm{NO}_{2}^{-}$assimilation : $\mathrm{NO}_{3}^{-}$assimilation) derived from all data measured at observational stations.

scale (Maguer et al., 1999; Weston et al., 2004). On average, $\mathrm{NH}_{4}^{+}$assimilation represented $338 \%$ of the $\mathrm{NH}_{4}^{+}$supplied by $\mathrm{NH}_{4}^{+}$regeneration, $\mathrm{NO}_{2}^{-}$assimilation represented $155 \%$ of $\mathrm{NO}_{2}^{-}$supplied by $\mathrm{NH}_{4}^{+}$oxidation and $\mathrm{NO}_{3}^{-}$assimilation represented $115 \%$ of the $\mathrm{NO}_{3}^{-}$supplied by $\mathrm{NO}_{2}^{-}$oxidation (with the omission of one outlying station at which extremely low $\mathrm{NO}_{2}^{-}$oxidation was measured). However, it is important to note that process rates were derived over different time frames; $24 \mathrm{~h}$ incubations for $\mathrm{N}$-regeneration studies included diel variability whereas $6 \mathrm{~h} \mathrm{~N}$-assimilation incubations did not. If it was assumed that $\mathrm{N}$-assimilation rates were maintained at the measured rate for the duration of the light phase $(18 \mathrm{~h})$, but ceased during the dark, then the assimilation of $\mathrm{NH}_{4}^{+}, \mathrm{NO}_{2}^{-}$and $\mathrm{NO}_{3}^{-}$would account for 225 , 103 and $77 \%$ of the $\mathrm{NH}_{4}^{+}, \mathrm{NO}_{2}^{-}$and $\mathrm{NO}_{3}^{-}$regenerated during a $24 \mathrm{~h} \mathrm{light} /$ dark cycle. While the complete cessation of dark $\mathrm{N}$-assimilation may be unrealistic (Clark et al., 2002; Flynn et al., 2002), this observation suggests that the regeneration / assimilation of oxidised nitrogen $\left(\mathrm{NO}_{2}^{-} / \mathrm{NO}_{3}^{-}\right)$is approximately balanced on a daily basis but that $\mathrm{NH}_{4}^{+}$regeneration / assimilation is unbalanced. This may be a consequence of the sampling strategy; additional $\mathrm{NH}_{4}^{+}$sources excluded from bottle incubations may have included the excretion products of heterotrophic grazers (notably those $>100 \mu \mathrm{m}$ ) which may not be quantitatively represented due to the time and method of seawater collection.

Consequently, nitrogen regenerated within incubation bottles was capable of making a significant contribution to phytoplankton nitrogen assimilation. Presumably, the microbial degradation of labile organic matter would sustain this recycling activity over a finite time frame within a bottle, but would be sustained in situ by advective transport or diffusive/turbulent mixing mechanisms. Dissolved organic matter directly released from phytoplankton during periods of high productivity (e.g. associated with bloom events), or from the benthos following the sedimentation and subsequent degradation of particulate matter could prolong phytoplankton productivity (Sintes et al., 2010). Consistent with this mechanism, Van Engeland et al. (2010) reported that in the North Sea, strong cycling of organic matter, notably of dissolved organic nitrogen (DON), constrained accumulation in the water column of open ocean stations, implying that bacterial DON degradation and $\mathrm{NH}_{4}^{+}$regeneration were important processes sustaining phytoplankton growth. The significance of nitrogen regeneration was also highlighted in the modelling study of Kühn and Radach (1997), based on an investigation of the North Sea spring bloom, which suggested that $\mathrm{NH}_{4}^{+}$regeneration took place throughout the water column but was strongest within the upper $30 \mathrm{~m}$.

The potential for pelagic nitrification within the temperate NW European shelf sea was demonstrated following the isolation of Crenarchaeota (now known as Thaumarchaeota, Spang et al., 2010) from a coastal North Sea region (Wuchter et al., 2006). A subsequent study in the southern North Sea demonstrated spatial and temporal variability in archaeal abundance (Herfort et al., 2007) while stable isotope evidence supported a prominent role for pelagic nitrification in the North Sea nitrogen cycle (Dähnke et al., 2010). However, contradictory results for the relative importance of bacterial and archaeal nitrifiers in the coastal North Sea (Wutcher et al., 2006; Veuger et al., 2013) highlighted the need for combined studies of microbial composition and direct rate measurement. To date, few studies have reported nitrification rates and the significance of $\mathrm{NO}_{2}^{-}$and $\mathrm{NO}_{3}^{-}$regeneration to the shelf sea nitrogen cycle remains unresolved. Using the ${ }^{15} \mathrm{~N}$-based $\mathrm{NH}_{4}^{+}$diffusion method Veuger et al. (2013) determined $\mathrm{NH}_{4}^{+}$oxidation rates of 43-221 nmol N L ${ }^{-1} \mathrm{~h}^{-1}$ in the coastal North Sea while Rees et al. (2002) using the allylthiourea $/{ }^{14} \mathrm{C}$ inhibitor method reported rates in the upper $40 \mathrm{~m}$ of the northern North Sea in the range $1-18 \mathrm{nmolNL}^{-1} \mathrm{~h}^{-1}$. During the present study, $\mathrm{NH}_{4}^{+}$oxidation $\left(0.20-1.85 \mathrm{nmol} \mathrm{N} \mathrm{L}^{-1} \mathrm{~h}^{-1}\right)$ and $\mathrm{NO}_{2}^{-}$ oxidation $\left(0.05-28.97 \mathrm{nmol} \mathrm{N} \mathrm{L}^{-1} \mathrm{~h}^{-1}\right)$ was measured indicating that $\mathrm{NO}_{3}^{-}$was actively recycled within the photic zone of the NW European shelf seas. On average, $12 \%$ (range 0.3$39.1 \%$ ) of regenerated $\mathrm{NH}_{4}^{+}$entered the nitrification pathway and the two stages of nitrification were uncoupled. Uncoupled nitrification has been reported in previous studies of the photic zone (Clark et al., 2008, 2011), possibly reflecting differential sensitivity of the separate stages to environmental drivers such as light and nutrients. Changes in environmental conditions with depth, predominantly of light, are likely to modify the rates at which $\mathrm{NH}_{4}^{+}$and $\mathrm{NO}_{2}^{-}$oxidation proceed and hence the strength of coupling between them. 
The $\mathrm{NH}_{4}^{+}$regeneration and nitrification activity measured at observational stations resulted in rapid DIN pool turnover (data not shown) which on average was $<3$ days for $\mathrm{NH}_{4}^{+}$, $<6$ days for $\mathrm{NO}_{2}^{-}$and $<23$ days for $\mathrm{NO}_{3}^{-}$(or $<3$ days if outlying data for Julian day 166 was removed, which arose due to an exceptionally low $\mathrm{NO}_{2}^{-}$oxidation rate). These values compared favourably with the range of 1-15 days reported for the southern North Sea during the summer (Weston et al., 2004) and implied that in regions not directly influenced by new nitrogen inputs (e.g. riverine sources), the inorganic nitrogen pool substantively represented regenerated nitrogen.

During this study, the analysis of $\mathrm{N}_{2} \mathrm{O}$ profiles suggested that the concentration of this greenhouse gas was comparable to that of the lower atmosphere, with percentage saturation in the range 99.4-102.4 (95\% confidence interval for the population median, $n=229$ ). In the oxygenated water columns investigated, $\mathrm{N}_{2} \mathrm{O}$ consumption due to denitrification would not be a significant sink (Thomson et al., 2012). In contrast, the first stage of nitrification has been linked with $\mathrm{N}_{2} \mathrm{O}$ production (Löscher et al., 2012), making the oceans a major source of $\mathrm{N}_{2} \mathrm{O}$ to the atmosphere by contributing approximately $30 \%$ (Bange et al., 2010). Estuaries such as those of the NW European shelf sea region have been shown to represent a significant source of $\mathrm{N}_{2} \mathrm{O}$ to the atmosphere (Barnes and Upstill-Goddard, 2011). However, results of this study indicated that open waters could not be viewed as a strong source or sink, consistent with previous observations which suggest that the open waters of shelf sea systems contribute only $0.5 \%$ to global atmospheric $\mathrm{N}_{2} \mathrm{O}$ (Freing et al., 2012).

Two sampling regions provided insights into nitrogen cycle activity which deserved further consideration. The first was the time series station E1 of the Western Channel Observatory (http://www.westernchannelobservatory.org.uk/) at which two station visits were separated by the passage of a storm. The second was a waning coccolithophorid bloom in the central North Sea. Observational studies were undertaken at station E1 during Julian days 166 and 175 between which storm conditions modified water column structure and nutrient distribution (Fig. 7). Prior to the storm, the water column was stratified and a strong chlorophyll maximum was evident at the base of the upper mixed layer in close association with the nutricline. The PON concentration was $1.25 \pm 0.06 \mu \mathrm{mol} \mathrm{N} \mathrm{L}{ }^{-1}$. Following the storm, stratification was weakened, and cooler nutrient-rich water was associated with shallower depths. The distinctive chlorophyll distribution prior to the storm was dissipated and replaced by higher chlorophyll concentrations at depths closer to the surface. The PON concentration was $1.40 \pm .20 \mu \mathrm{mol} \mathrm{N} \mathrm{L}^{-1}$. This change in water column structure coincided with a change in nitrogen cycle activity; $\mathrm{NH}_{4}^{+}, \mathrm{NO}_{2}^{-}$and $\mathrm{NO}_{3}^{-}$assimilation rates increased as did the rate of $\mathrm{NH}_{4}^{+}$regeneration. $\mathrm{NH}_{4}^{+}$oxidation rate dropped and the rate of $\mathrm{NO}_{2}^{-}$oxidation increased approximately 25 fold. While data provide only a limited insight into the chain of events we interpret

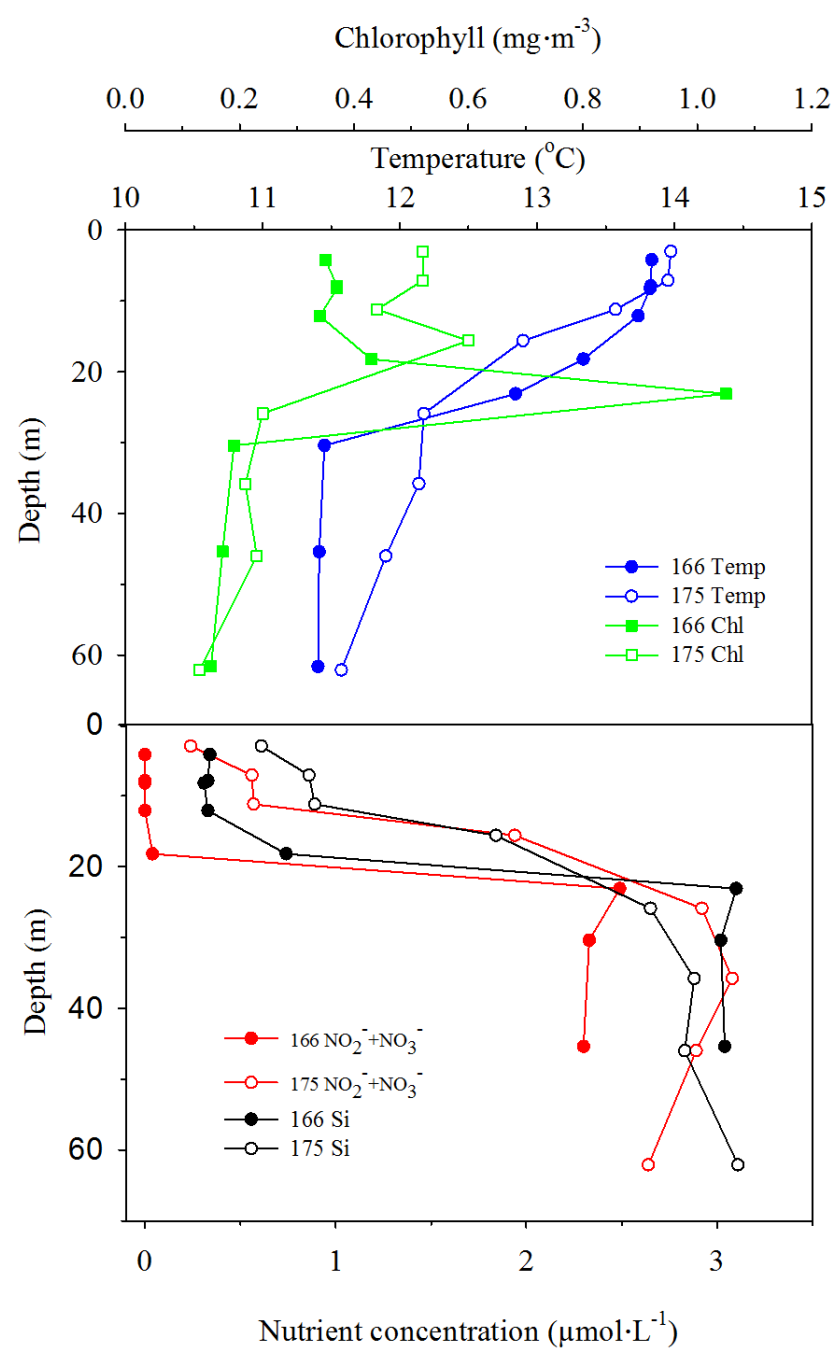

Figure 7. Water column profiles for Western Channel Observatory time series station E1 for Julian days 166 and 175.

this activity to reflect the physical transportation of highly active nitrifying organisms usually resident close to, or below the base of the photic zone, to the near-surface where they maintained uncharacteristically high activity (compared to observations at similar depth elsewhere). This activity was likely to be short-lived and limited by the depletion of substrate or photo-inhibition. We interpret the enhanced nitrogen assimilation rates, notably the assimilation of oxidised nitrogen, as a reflection of increased DIN availability due to both the initial mixing event and then subsequent nitrogen recycling activity.

The second region of interest was located in the northern North Sea where high-resolution sampling across a coccolithophorid bloom was undertaken for 2 days, incorporating bloom, bloom edge and non-bloom stations. Only two of these stations were sampled for nitrogen cycle activity; out of the bloom on Julian day 179 and within bloom on Julian day 180 . Relatively high rates of $\mathrm{NH}_{4}^{+}$and $\mathrm{NO}_{2}^{-}$assimilation 

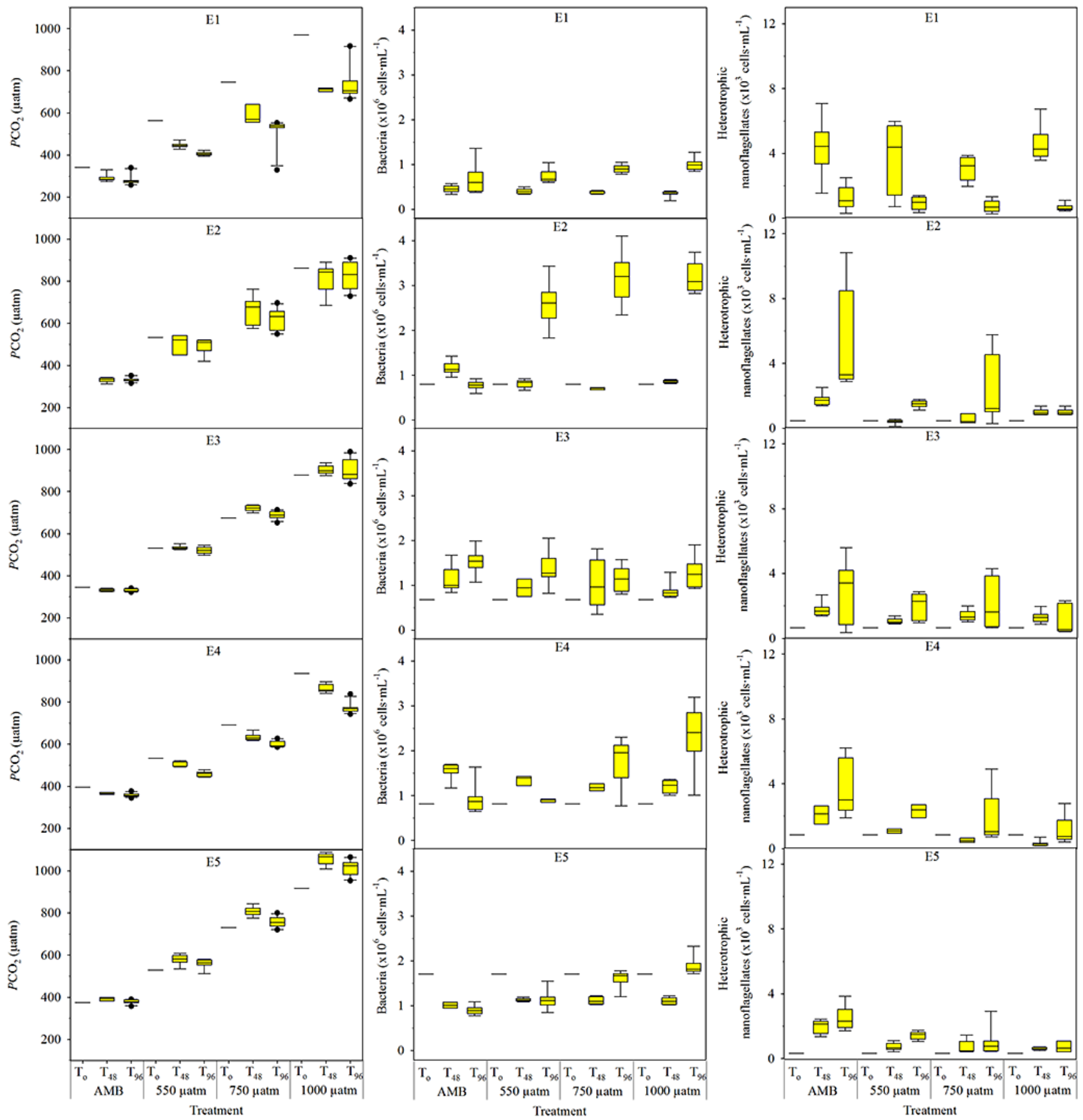

Figure 8. $\mathrm{PCO}_{2}$, total bacterial abundance and the abundance of heterotrophic nanoflagellates derived from bioassay experiments (E1-5) for each treatment and time point. Treatment labels represent the initial intended $\mathrm{PCO}_{2}$ value.

were measured at both "bloom" and "non-bloom" stations while the $\mathrm{NO}_{3}^{-}$assimilation rate was lower within the bloom. A notable feature was that the separate stages of nitrification were closely coupled within the bloom station (coupling ratio of 0.78 compared to an average of 0.22 for $\mathrm{NH}_{4}^{+}: \mathrm{NO}_{2}^{-}$oxidation for all observational data) which was the only point at which this was observed. Seawater was collected at a similar time for both stations (approximately 8.15 a.m. G.M.T) from the $55 \%$ sPAR depth (5.7 and $3.4 \mathrm{~m}$ for Julian days 179 and 180 respectively) at which down-welling $2 \pi$ scalar irradiance was 0.97 vs. $0.56 \mathrm{~W} \mathrm{~m}^{-2}$. While light intensity was weaker within the bloom, it is likely that spectral quality also differed significantly. We speculate that this difference in both light intensity and spectral quality, which has been shown to mediate nitrification activity (Guerrero and Jones, 1996), may have influenced the strength of coupling between 

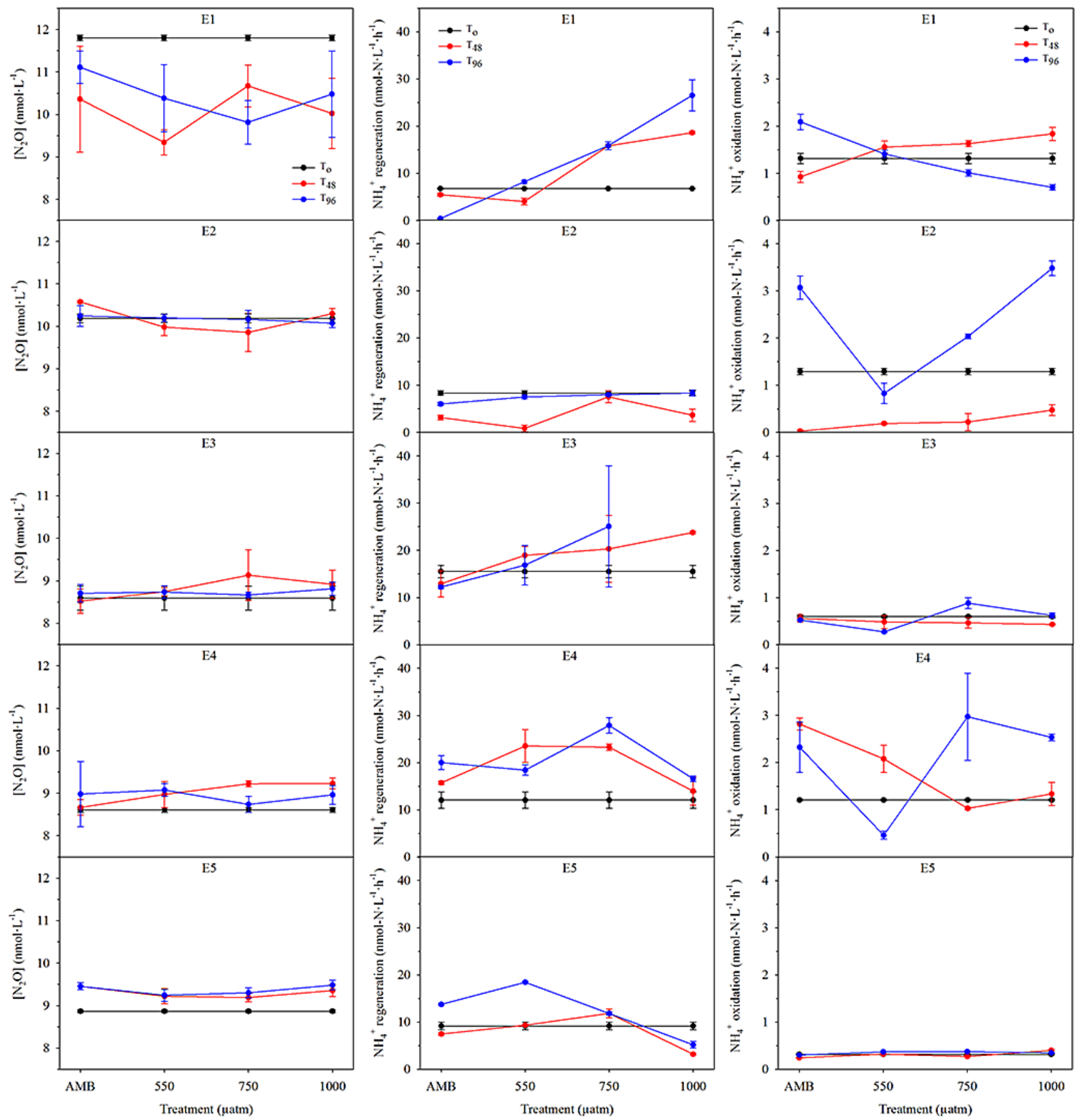

Figure 9. Bioassay data for changes in $\mathrm{N}_{2} \mathrm{O}$ concentration, $\mathrm{NH}_{4}^{+}$regeneration rate and $\mathrm{NH}_{4}^{+}$oxidation rate during bioassay experiments Note that $T_{0}$ values were only measured in ambient treatments. Values are copied over to 550, 750 and $1000 \mu$ atm $P \mathrm{CO}_{2}$ treatments to aid comparisons. Treatment labels represent the initial intended $\mathrm{PCO}_{2}$ value.

the stages of nitrification, resulting in a higher than average fraction of regenerated $\mathrm{NH}_{4}^{+}$entering the nitrification pathway at the sea surface $(21 \%$ vs. $12 \%)$ within the bloom. It remains to be tested whether modification of the light field by coccolithophorid blooms generally strengthens the coupling between $\mathrm{NH}_{4}^{+}$and $\mathrm{NO}_{2}^{-}$oxidation processes and ultimately enhances the supply of regenerated $\mathrm{NO}_{3}^{-}$within near-surface seawater.

In an attempt to understand the links between nitrogen cycle variability and environmental variables, we undertook statistical analysis to identify parameter combinations which could explain variability in nitrogen cycle observations. Ultimately, the aim was to contribute towards the development of 
a mechanistic understanding of nitrogen cycle activity. Results indicated that although there were differences among sites in terms of their physio-chemical variables, there was no evidence that these were related to any of the measured response variables including nitrogen cycle parameters, or that the measurements of response variables represented anything other than random variability. Factors which may have influenced this outcome included the limited number of observations, and the extent to which the system could be described with the selected response variables. In addition, there was the possibility that microbial rates reflected conditions associated with the recent past rather than those at the point of sampling, which are not necessarily the same in a dynamic environment. Results imply that in order to draw significant links between $\mathrm{N}$-cycle parameters and physiochemical variables a more comprehensive description of the biological system is required. The analysis highlighted the risk that in the absence of comprehensive analysis, undue significance could be placed upon links between response and explanatory variables. Consequently, observational results presented here allowed us only to confirm that specific nitrogen cycle processes were active and to offer a range over which they took place. We are left to speculate as to the underlying reasons for the distribution and range of observations.

\subsection{Response of nitrogen regeneration processes to simulated ocean acidification conditions}

The bioassay approach used here facilitated rigorous control of incubation conditions, allowing investigators to examine changes in biological and chemical composition of seawater in response to a $\mathrm{PCO}_{2}$ gradient. In common with laboratory or mesocosm studies, bottle bioassays allowed for replication and statistical analysis, with the added advantage that a ship-based approach allowed different geographical locations to be sampled. While anticipating differences in biogeochemical characteristics between locations (i.e. differences in the concentration of dissolved compounds or the rates at which specific processes progressed), our hypothesis was that the underlying mechanism through which pelagic biota responded to OA conditions would be independent of location. Our objective was to develop a mechanistic understanding of how $\mathrm{N}$-regeneration (nitrification, $\mathrm{NH}_{4}^{+}$regeneration) and $\mathrm{N}_{2} \mathrm{O}$ production responded to simulated OA conditions. The underlying rationale for this approach was to test the intrinsic assumption of ecosystem models that biological process rate descriptions (potentially derived from a single location and time) can be extrapolated across geographical areas within a modelled domain. During bioassay experiments we anticipated that potential treatment effects would reflect the growth and activity of organisms with division rates comparable to, or less than, the duration of the experiment (Flynn et al., 2012; de Kluijver et al., 2013). This would include both cellular acclimation responses and changes in community composition. By extension, this activity was anticipated to drive potential changes in seawater composition, such as dissolved inorganic nutrient and gas concentrations. Evidence for treatment effects was not anticipated for bulk dissolved organic pool concentrations, due to the combination of high concentration and slow turnover (de Kluijver et al., 2013).

Caveats were associated with the use of prolonged bottle incubations; while the photoperiod matched the geographical location sampled, the spectral quality of light within incubation bottles differed from natural light and may have influenced phototrophic activity; there was potential for progressive deviation in community composition and activity from that of natural communities due to bottle confinement, which prevented nutrient and metabolite exchange processes and may have selectively enhanced/suppressed the activity of specific community components (Timmermans et al., 1998; Calvo-Díaz et al., 2011). It is unclear how these factors influenced the results presented.

The locations chosen for bioassay experiments differed in their biogeochemical characteristics, as indicated by contour plots (Fig. 3), $T_{0}$ values of selected parameters (Figs. 8, 9) and macro-scale features (Fig. 2). For example, the initial concentration of $\mathrm{NO}_{3}^{-}$and $\mathrm{PO}_{4}^{3-}$ varied over 6-fold, the abundance of bacteria and heterotrophic nanoflagellates varied 2.5-fold, phototrophic nano- and pico-plankton varied 7 -fold and Synechococcus abundance varied $>45$-fold. Results demonstrated that the magnitude, and on occasion, the direction of change in the value of measured parameters differed between experiments as bioassays progressed (the present study, Richier et al., 2014a). Progressive changes in $\mathrm{pH}$ and carbonate chemistry observed during these bioassays have been noted in previous OA experiments (Bellerby et al., 2008; Niehoff et al., 2013); this departure from initial conditions added complexity to the interpretation of results.

The response of $\mathrm{N}_{2} \mathrm{O}$ concentration and nitrogen cycle parameters is presented in Fig. 9. The concentration and process rate ranges measured during bioassay experiments were comparable to those measured at observational stations. However, the response to $\mathrm{PCO}_{2}$ treatments was ambiguous. While direct observations of $\mathrm{NH}_{4}^{+}$regeneration rate responses to simulated OA conditions are lacking to our knowledge, Piontek et al. (2013) measured enhanced rates of bacterial extracellular hydrolytic enzyme activity during both acidification bioassay and mesocosm studies, indicating the potential for enhanced nutrient regeneration under OA conditions. By contrast, observations suggest that OA conditions inhibit $\mathrm{NH}_{4}^{+}$oxidation (Beman et al., 2011; Huesemann et al., 2002) and implications for $\mathrm{N}_{2} \mathrm{O}$ concentration would be anticipated. While this hypothesis has been contradicted (Fulweiler et al., 2011), cursory observation of our results offered no support for a consistent treatment-related response in the rate of $\mathrm{NH}_{4}^{+}$oxidation or regeneration, or in the concentration of $\mathrm{N}_{2} \mathrm{O}$. However, data set complexity required a more sophisticated analytical approach in order to draw out 


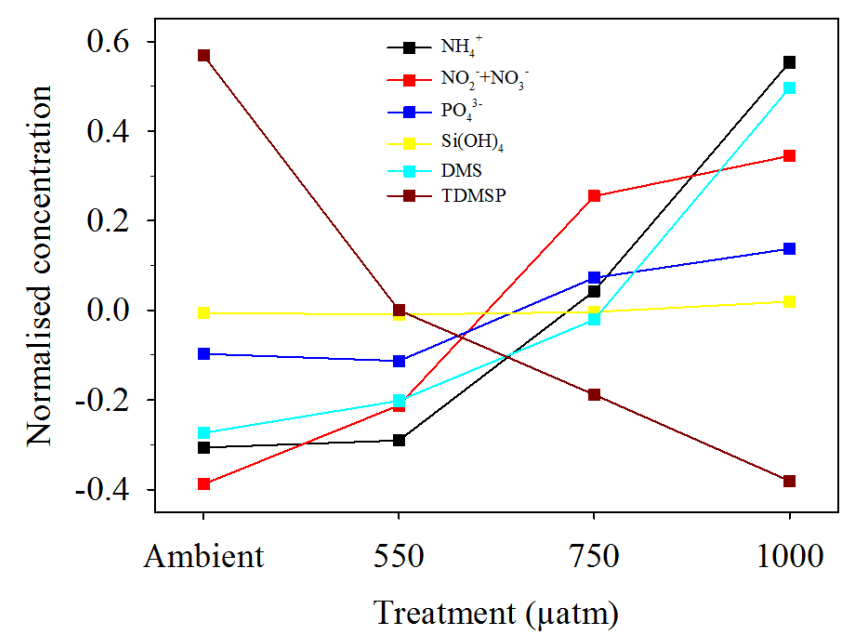

Figure 10. Normalised plot of changes in inorganic nutrient and DMS/TDMSP concentration with $\mathrm{PCO}_{2}$ treatment for collated bioassay data.

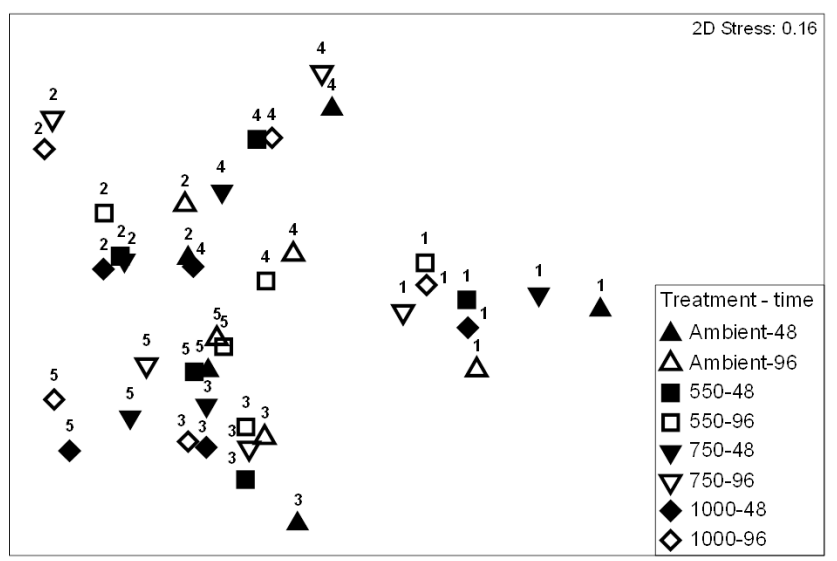

Figure 11. Non-metric multidimensional scaling (MDS) ordination of samples based on normalised Euclidean distances. Labels denote bioassay number.

potential treatment responses. This was undertaken using a range of statistical techniques.

The primary conclusion to be drawn from the statistical analysis of OAB data was that we were able to extract little in the way of useful information about the effects of acidification on any of the measured groups of variables, with the possible exception of nutrient concentrations, as discussed below. Experiments from different places produced different results. While some of the experimental units demonstrated differences among treatments, there was little evidence that these results were consistent or meaningful. While it could be argued that the analysis presented here was based on groups of variables and therefore differed from a study which focused on a single variable or a limited subset, we argue that there must be some defendable reason for selecting variables a priori before conducting such an analysis. During this in- vestigation we recognised the danger of selective data representation; that is, scanning across variables and relationships among variables, across and within locations, to draw out subsets that produced results that were in tune with preconceptions. We noted that there were 44 variables in the full data set and 946 relationships among them, ignoring colinearity, and for the purposes of a broad demonstration, if approximately $5 \%$ of these were expected to be "significant" by chance then we should expect somewhere in the order of 50 spurious relationships. If we were to examine each location separately we would be looking at in excess of 24000 potential relationships, of which 1200 could have appeared to be significant even if there were no genuine relationships among them to interpret. Our analyses demonstrated that measurements from each location expressed different patterns, that of the different factors included, the $\mathrm{PCO}_{2}$ treatments had the least effect, and that there were no clear patterns consistently associated with the $\mathrm{PCO}_{2}$ treatments. Consequently, a mechanistic basis for the response of marine biota to simulated OA conditions could not be provided. By extension, neither the response of nitrifying organisms, the response of $\mathrm{NH}_{4}^{+}$regenerating organisms or the concentration of $\mathrm{N}_{2} \mathrm{O}$ allowed for the development of a mechanistic understanding of these nitrogen cycle components to simulated OA conditions. It remains to be tested how N-cycle results would differ if bioassay experiments were repeated using seawater collected from below the photic zone (escaping for example, light inhibition of nitrification; Olson, 1981), where rates of N-regeneration processes are likely to be higher, and potential treatment responses less ambiguous.

Results suggested that the biological community of the NW European shelf sea may be insensitive to ocean acidification conditions. However, while no significant treatment response was consistently identified between groups of variables at all locations and time points, results indicated that a significant treatment response was identified for inorganic nutrient concentrations alone (Table 4). It must be re-iterated that $P \mathrm{CO}_{2}$ treatment explained least of the data variability in our analysis (Table 5). Within this constraint, further examination of changes in nutrient concentration (Fig. 11) indicated that the relative concentration of $\mathrm{NH}_{4}^{+}, \mathrm{NO}_{3 / 2}^{-}, \mathrm{PO}_{4}^{3-}$ and dimethylsulfide (DMS) increased with $\mathrm{PCO}_{2}$ treatment while total dimethylsulfoniopropionate (TDMSP) decreased and $\mathrm{Si}$ was unchanged. A direct effect of $\mathrm{pH}$ on $\mathrm{NH}_{4}^{+}$concentration has been suggested (Wyatt et al., 2010), and a similar mechanism may contribute to the speciation and availability of other nutrient ions. However, we speculate that this observation is substantively related to biological activity. Since nutrient concentration may be viewed as an integrated measure of the balance between production and consumption processes, we speculate that these results allude to a shortterm biological response to $P \mathrm{CO}_{2}$ treatment. After location, factors excluded from the parameter set explained the greatest variability in bioassay data, potentially indicating that the most significant biological processes responsible for this 
observation were not measured. By necessity, such processes must have been facilitated by microbial community components capable of a rapid response, potentially including nutrient assimilation by both phytoplankton and bacteria, and virally induced cell lysis. Consequently, although our analysis indicated that short-term changes in nutrient concentrations were related to OA treatments, these were not linked with N-regeneration activity in any significant way. Our specific hypothesis could not be supported. Further work needs to be undertaken to elucidate how this finding relates to microbial community activity and how this may relate to the longer-term community-level response.

\section{Concluding remarks}

Results presented here add to, rather than diminish from the complexity of understanding the marine biota response to projected OA conditions. The biological response to OA conditions varied between locations, highlighting the need for studies to incorporate a broader geographical spread in order to test the resilience of OA-related findings, especially in dynamic systems. Although a mechanistic understanding could not be developed from our analysis, it does not dismiss this possibility. Rather, it raises the question about which combination of biogeochemical characteristics drives the shortterm biological response to ocean acidification.

Acknowledgements. This work is a contribution to the UK Ocean Acidification Research Programme (UKOA) which was jointly funded by the Department for Environment, Food and Rural Affairs (Defra), the Natural Environment Research Council (NERC) and the Department of Energy and Climate Change (DECC) under grant agreement no. NE/H017259/1. We thank the cruise participants for contributing data for statistical analysis and the captain and crew of RSS Discovery for assistance during the cruise.

Edited by: E. Achterberg

\section{References}

Anderson, M. J.: A new method for non-parametric multivariate analysis of variance, Austral Ecol., 26, 32-46, doi:10.1111/j.1442-9993.2001.01070.pp.x, 2001.

Anderson, M. J., Gorley, R. N., and Clarke, K. R.: PERMANOVA+ for PRIMER: Guide to software and statistical methods, PrimerE, Plymouth UK, 2008.

Bange, H. W., Freing, A., Kock, A., and Löscher, C. R.: Marine pathways to nitrous oxide $\left(\mathrm{N}_{2} \mathrm{O}\right)$, in: Nitrous oxide and climate change, edited by: Smith, K., 36-62, London, UK, Earthscan, 2010

Barnes, J. and Upstill-Goddard, R. C.: $\mathrm{N}_{2} \mathrm{O}$ seasonal distributions and air-sea exchange in UK estuaries: Implications for the tropospheric $\mathrm{N}_{2} \mathrm{O}$ source from European coastal waters, J. Geophys. Res., 116, G01006, doi:10.1029/2009JG001156, 2011.
Beaufort, L., Probert, I., de Garidel-Thoron, T., Bendif, E. M., RuizPino, D., Metzl, N., Goyet, C., Buchet, N., Coupel, P., Grelaud, M., Rost, R., Rickaby, R. E. M., and de Vargas, C.: Sensitivity of coccolithophores to carbonate chemistry and ocean acidification, Nature, 476, 80-83, doi:10.1038/nature10295, 2011.

Bellerby, R. G. J., Schulz, K. G., Riebesell, U., Neill, C., Nondal, G., Heegaard, E., Johannessen, T., and Brown, K. R.: Marine ecosystem community carbon and nutrient uptake stoichiometry under varying ocean acidification during the PeECE III experiment, Biogeosciences, 5, 1517-1527, doi:10.5194/bg-5-15172008, 2008.

Beman, J. M., Chow, C., King, A. L., Feng, Y., Fuhrman, J. A., Andersson, A., Bates, N. R., Popp, B. N., and Hutchins, D. A.: Global declines in oceanic nitrification rates as a consequence of ocean acidification, P. Natl. Acad. Sci. USA, 108, 208-213, doi:10.1073/pnas.1011053108, 2011.

Blackburn, T. H.: Method for measuring rates of $\mathrm{NH}_{4}^{+}$turnover in anoxic marine sediments, using a ${ }^{15} \mathrm{~N}-\mathrm{NH}_{4}^{+}$dilution technique, Appl. Environ. Microbiol., 37, 760-765, 1979.

Caldeira, K. and Wickett, M. E.: Anthropogenic carbon and ocean pH, Nature, 425, 365, doi:10.1038/425365a, 2003.

Calvo-Díaz, A., Díaz-Pérez, L., Suárez, L. A., Morán, X. A. G., Teira, E., and Marañón, E.: Decrease in the autotrophic-toheterotrophic biomass ratio of picoplankton in oligotrophic marine waters due to bottle enclosure, Appl. Environ. Microbiol., 77, 5739-5746, doi:10.1128/AEM.00066-11, 2011.

Caperon, J., Schell, D., Hirota, J., and Laws, E.: Ammonium excretion rates in Kaneohe Bay, Hawaii, measured by a ${ }^{15} \mathrm{~N}$ isotope dilution technique, Mar. Biol., 54, 33-40, 1979.

Clark, D. R., Flynn, K. J., and Owens, N. J. P.: The large capacity for dark nitrate-assimilation in diatoms may overcome nitrate limitation of growth, New Phycol., 155, 101-108, 2002.

Clark, D. R., Fileman, T. W., and Joint, I.: Determination of ammonium regeneration rates in the oligotrophic ocean by gas chromatography/mass spectrometry, Mar. Chem., 98, 121-130, doi:10.1016/j.marchem.2005.08.006, 2006.

Clark, D. R., Rees, A. P., and Joint, I.: A method for the determination of nitrification rates in oligotrophic marine seawater by gas chromatography/mass spectrometry, Mar. Chem., 103, 8496, doi:10.1016/j.marchem.2006.06.005, 2007

Clark, D. R., Rees, A. P., and Joint, I.: Ammonium regeneration and nitrification rates in the oligotrophic Atlantic Ocean: Implications for new production estimates, Limnol. Oceanogr., 53, 5262,2008

Clark, D. R., Miller, P. I., Woodward, E. M. S., and Rees, A. P.: Inorganic nitrogen assimilation and regeneration in the coastal upwelling region of the Iberian Peninsula, Limnol. Oceanogr., 56, 1689-1702, doi:10.4319/lo.2011.56.5.1689, 2011.

Clark, D. R., Flynn, K. F., and Fabian, H.: Variation in elemental stoichiometry of the marine diatom Thalassiosira weissflogii (Bacillariophyceae) in response to combined nutrient stress and changes in carbonate chemistry, J. Phycol., 50, 640-6511, doi:10.1111/jpy.12208, 2014.

Clarke, K. R. and Gorley, R. N.: PRIMER v6: User manual/Tutorial, Primer-E, Plymouth UK, 2006.

Clarke, K. R., Somerfield, P. J., and Gorley, R. N.: Exploratory null hypothesis testing from community data: similarity profiles and biota-environment linkage, J. Exp. Mar. Biol. Ecol., 366, 56-69, doi:10.1016/j.jembe.2008.07.009, 2008. 
Cooley, S. R., Kite-Powel 1, H. L., and Doney, S. C.: Ocean Acidification's Potential to Alter Global Marine Ecosystem Services, Oceanography, 22, 172-181, 2009.

Dähnke, K., Emeis, K., Johannsen, A., and Nagel, B.: Stable isotope composition and turnover of nitrate in the German Bight, Mar. Ecol.-Prog. Ser., 408, 7-18, doi:10.3354/meps08558, 2010.

de Kluijver, A., Soetaert, K., Czerny, J., Schulz, K. G., Boxhammer, T., Riebesell, U., and Middelburg, J. J.: A 13C labelling study on carbon fluxes in Arctic plankton communities under elevated CO2 levels, Biogeosciences, 10, 1425-1440, doi:10.5194/bg-101425-2013, 2013.

Dugdale, R. C. and Goering, J. J.: Uptake of new and regenerated forms of nitrogen in primary productivity, Limnol. Oceanogr, 12, 196-206, 1967

Flynn, J. K., Clark, D. R., and Owens, N. J. P.: Modelling suggests that optimization of dark nitrogen-assimilation need not be a critical selective feature in phytoplankton, New Phycol., 155, 109119, 2002.

Flynn, K. J., Blackford, J. C., Baird, M. E., Raven, J. A., Clark, D. R., Beardall, J., Brownlee, C., Fabian, H., and Wheeler, G. L.: Changes in $\mathrm{pH}$ at the exterior surface of plankton with ocean acidification, Nature Climate Change, 2, 510-513, doi:10.1038/NCLIMATE1696, 2012.

Freing, A., Wallace, D. W. R., and Bange, H. W.: Global oceanic production of nitrous oxide, Phil. Trans. R. Soc. B. 367, 12451255, doi:10.1098/rstb.2011.0360, 2012.

Fulweiler, R. W., Emery, H. E., Heiss, E. M., and Berounsky, V. M.: Assessing the role of $\mathrm{pH}$ in determining water column nitrification rates in a coastal system, Est. Costal Sci., 34, 1095-1102, doi:10.1007/s12237-011-9432-4, 2011.

Gattuso, J.-P. and Lavigne, H.: Technical Note: Approaches and software tools to investigate the impact of ocean acidification, Biogeosciences, 6, 2121-2133, doi:10.5194/bg-6-21212009, 2009.

Gattusso, J. P. and Hansson, L.: European Project on Ocean Acidification (EP OCA), Oceanography, 22, 190-201, doi:10.5670/oceanog.2009.108, 2009.

Guerrero, M. A. and Jones, R. D.: Photoinhibition of marine nitrifying bacteria, I. Wavelength-dependent response, Mar. Ecol.-Prog. Ser., 141, 183-192, 1996.

Herfort, L., Schouten, S., Abbas, B., Velhuis, M. J. W., Coolen, M. J. L., Wuchter, C., Boon, J. P., Herndl, G. J., and Damsté, J. S. S.: Variations in spatial and temporal distribution of Archaea in the North Sea in relation to environmental variables, FEMS Microbiol Ecol., 62, 242-257, doi:10.1111/j.1574-6941.2007.00397.x, 2007.

Huesemann, M. H., Skillman, A. D., and Crecelius, E. A.: The inhibition of marine nitrification by ocean disposal of carbon dioxide, Mar. Pollut. Bull., 44, 142-148, 2002.

Hutchins, D. A., Mulholland, M. R., and Feixue, F.: Nutrient cycles and marine microbes in a $\mathrm{CO}_{2}$-enriched ocean, Oceanography, 22, 128-145, doi:10.5670/oceanog.2009.103, 2009.

Jahnke, R. A.: A Global Synthesis, in: Carbon and nutrient fluxes in continental margins, edited by: Liu, K.-K., Atkinson, L., Quiñones, R., and Talaue-McManus, L., Springer-Verlag, 597615,2010

Kanda, J., Laws, E. A., Saino, T., and Hattori, A.: An evaluation of isotope dilution effect from conventional data sets of ${ }^{15} \mathrm{~N}$ uptake experiments, J. Plankton Res., 19, 79-90, 1987.
Kühn, W. and Radach, G.: A one-dimensional physical-biological model study of the pelagic nitrogen cycling during the spring bloom in the northern North Sea (FLEX '76), J. Mar. Res., 55, 687-734, 1997.

Liu, K. K., Atkinson, L., Quiñones, R. A., and Talaue-McManus, L.: Biogeochemistry of Continental Margins in a Global Context, in: Carbon and nutrient fluxes in continental margins, edited by: Liu, K.-K., Atkinson, L., Quiñones, R., and Talaue-McManus, L., Springer-Verlag, 3-24, 2010.

Lomas, M. W. and Lipschultz, F.: Forming the primary nitrite maximum: Nitrifiers or phytoplankton?, Limnol. Oceanogr., 51, 2453-2467, doi:10.4319/lo.2006.51.5.2453, 2006.

Löscher, C. R., Kock, A., Könneke, M., LaRoche, J., Bange, H. W., and Schmitz, R. A.: Production of oceanic nitrous oxide by ammonia-oxidizing archaea, Biogeosciences, 9, 2419-2429, doi:10.5194/bg-9-2419-2012, 2012.

Maguer, J.-F., L'Helguen, S., Madec, C., and Le Corre, P.: Seasonal patterns of ammonium regeneration from size-fractionated microheterotrophs, Cont. Shelf. Res., 19, 1755-1770, 1999.

Maguer, J.-F., L'Helguen, S., Caradec, J., and Klein, C.: Sizedependent uptake of nitrate and ammonium as a function of light in well-mixed temperate coastal waters, Cont. Shelf Res., 31, 1620-1631, doi:10.1016/j.csr.2011.07.005, 2011.

McArdle, B. H. and Anderson, M. J.: Fitting multivariate models to community data: a comment on distance-based redundancy analysis, Ecology, 82, 290-297, 2001.

Miller, P., Groom, S., McManus, A., Selley, J., and Mironnet, N.: Panorama: a semi-automated AVHRR and CZCS system for observation of coastal and ocean processes. RSS97: Observations and Interactions, Proceedings of the Remote Sensing Society, Reading, 539-544, 1997.

Mulholland, M. R., Bernhardt, P. W., Heil, C. A., Bronk, D., and O'Neil, J. M.: Nitrogen fixation and release of fixed nitrogen by Trichodesmium spp. in the Gulf of Mexico, Limnol. Oceanogr., 51, 1762-1776, doi:10.4319/lo.2006.51.4.1762, 2006.

Niehoff, B., Schmithüsen, T., Knüppel, N., Daase, M., Czerny, J., and Boxhammer, T.: Mesozooplankton community development at elevated $\mathrm{CO}_{2}$ concentrations: results from a mesocosm experiment in an Arctic fjord, Biogeosciences, 10, 1391-1406, doi:10.5194/bg-10-1391-2013, 2013.

Olson, R. J.: Differential photoinhibition of marine nitrifying bacteria: A possible mechanism for the formation of the primary nitrite maximum, J. Mar. Res., 39, 227-238, 1981.

Orr, J. C., Fabry, V. J., Aumont, O., Bopp, L., Doney, S. C., Feely, R. A., Gnanadesikan, A., Gruber, N., Ishida, A., Joos, F., Key, R. M., Lindsay, K., Maier-Reimer, E., Matear, R., Monfray, P., Mouchet A., Najjar, R. G., Plattner, G., Rodgers, K. B., Sabine, C. L., Sarmiento, J. L., Schlitzer, R., Slater, R. D., Totterdell, I. J., Weirig, M., Yamanaka, Y., and Yool, A.: Anthropogenic ocean acidification over the twenty-first century and its impact on calcifying organisms, Nature, 437, 681-686, doi:10.1038/nature04095, 2005.

Piontek, J., Borchard, C., Sperling, M., Schulz, K. G., Riebesell, U., and Engel, A.: Response of bacterioplankton activity in an Arctic fjord system to elevated $p \mathrm{CO}_{2}$ : results from a mesocosm perturbation study, Biogeosciences, 10, 297-314, doi:10.5194/bg-10297-2013, 2013

Rees, A. P., Woodward, E. M. S., Robinson, C., Cummings, D. G., Tarran, G. A., and Joint, I.: Size-fractionated nitrogen uptake and 
carbon fixation during a developing coccolithophorid bloom in the North Sea during June 1999, Deep-Sea Res., 49, 2905-2927, 2002.

Rees, A. P., Gilbert, J. A., and Kelly-Gerreyn, B. A.: Nitrogen fixation in the western English Channel (NE Atlantic Ocean), Mar. Ecol.-Prog. Ser., 374, 7-12, doi:10.3354/meps07771, 2009.

Richier, S., Achterberg, E. P., Dumousseaud, C., Poulton, A. J., Suggett, D. J., Tyrrell, T., Zubkov, M. V., and Moore, C. M.: Carbon cycling and phytoplankton responses within highlyreplicated shipboard carbonate chemistry manipulation experiments conducted around Northwest European Shelf Seas, Biogeosciences Discuss., 11, 3489-3534, doi:10.5194/bgd-11-34892014, 2014a.

Richier, S., Achterberg, E. P., Archer, S., Bretherton, L., Brown, I., Clark, D., Dumousseaud, C., Holland, R. J., Hopkins, F. E., MacGilchrist, G. A., Moore, C. M., Poulton, A., Rees, A., Shi, T., Stinchcombe, M., Suggett, D., Zubkov, M. V., Young, J., and Tyrrell, T.: Ocean acidification impacts on Sea Surface biology and biogeochemistry in Northwest European Shelf Seas: a highreplicated shipboard approach, British Oceanographic Data Centre - Natural Environment Research Council, UK, doi:10/s8r, 2014b.

Ridgwell, A., Schmidt, D. N., Turley, C., Brownlee, C., Maldonado, M. T., Tortell, P., and Young, J. R.: From laboratory manipulations to Earth system models: scaling calcification impacts of ocean acidification, Biogeosciences, 6, 2611-2623, doi:10.5194/bg-6-2611-2009, 2009.

Riebesell, U., Bellerby, R. G. J., Grossart, H.-P., and Thingstad, F.: Mesocosm $\mathrm{CO}_{2}$ perturbation studies: from organism to community level, Biogeosciences, 5, 1157-1164, doi:10.5194/bg-51157-2008, 2008.

Riegman, R. and Noordeloos, A. A. M.: Size-fractionated uptake of nitrogenous nutrients and carbon by phytoplankton in the North Sea during summer 1994, Mar. Ecol.-Prog. Ser., 173, 95-106, 1998.

Riegman, R., Flameling, I. A., and Noordeloos, A. A. M.: Size fractionated uptake of ammonium, nitrate and urea and phytoplankton growth in the North Sea during Spring 1994, Mar. Ecol.-Prog. Ser., 173, 85-94, 1998.

Schulz, K. G., Riebesell, U., Bellerby, R. G. J., Biswas, H., Meyerhöfer, M., Müller, M. N., Egge, J. K., Nejstgaard, J. C., Neill, C., Wohlers, J., and Zöllner, E.: Build-up and decline of organic matter during PeECE III, Biogeosciences, 5, 707-718, doi:10.5194/bg-5-707-2008, 2008.

Shutler, J. D., Smyth, T. J., Land, P. E., and Groom, S. B.: A nearreal time automatic MODIS data processing system, International J. Remote Sens., 26, 1049-1055, 2005.

Sintes, E., Stoderegger, K., Parada, V., and Herndl, G. J.: Seasonal dynamics of dissolved organic matter and microbial activity in the coastal North Sea, Aqu. Mic. Ecol., 60, 85-95, doi:10.3354/ame01404, 2010.

Sweeney, R. E., Liu, K. K., and Kaplan, I. R.: Oceanic nitrogen isotopes and their uses in determining the source of sedimentary nitrogen, N. Z. Depart, Sci. Ind. Res. Bull., 220, 9-26, 1978.
Spang A., Hatzenpichler, R., Brochier-Armanet, C., Rattei, T., Tischler, P., Spieck, E., Streit, W., Stahl, D. A., Wagner, M., and Schleper, C.: Distinct gene set in two different lineages of ammonia-oxidizing archaea supports the phylum Thaumarchaeota, Trends Microbiol., 18, 331-340, doi:10.1016/j.tim.2010.06.003, 2010.

Thomson, A. J., Giannopoulos, G., Pretty, J., Baggs, E. M., and Richardson, D. J: Biological sources and sinks of nitrous oxide and strategies to mitigate emissions, Phil. Trans. R. Soc. B., 367, 1157-1168, 2012.

Timmermans, K. R., Gledhillb, M., Noltinga, R. F., Veldhuisa, M. J. W., de Baara, H. J. W., and van den Bergb, C. M. G.: Responses of marine phytoplankton in iron enrichment experiments in the northern north Sea and northeast Atlantic Ocean, Mar. Chem., 61, 229-242, 1998.

Upstill-Goddard, R. C., Rees, A. P., and Owens, N. J. P.: Simultaneous high-precision measurements of methane and nitrous oxide in water and seawater by single phase equilibration gas chromatography, Deep-Sea Res. Pt. I, 43, 1669-1682, doi:10.1016/S0967-0637(96)00074-X, 1996.

van Engeland, T., Soetaert, K., Knuijt, A., Laane, R. W. P. M., and Middelburg, J. J.: Dissolved organic nitrogen in the north sea: a time series analysis (1995-2005), Est. Costal Shelf Sea Sci., 89, 31-42, doi:10.1016/j.ecss.2010.05.009, 2010.

Veuger, B., Pitcher, A., Schouten, S., Sinninghe Damsté, J. S., and Middelburg, J. J.: Nitrification and growth of autotrophic nitrifying bacteria and Thaumarchaeota in the coastal North Sea, Biogeosciences, 10, 1775-1785, doi:10.5194/bg-10-1775-2013, 2013.

Wutcher, C., Abbas, B., Coolen, M. J. L., Herfort, L., van Bleijswijk, J., Timmers, P., Strous, M., Teira, E., Herndl, G., Middelburg, J. J., Schouten, S., and Damsté, J. S. S.: Archaeal nitrification in the ocean, P. Natl. Acad. Sci. USA, 103, 12317-12322, doi:10.1073/pnas.0600756103, 2006.

Wafar, M., L'Helguen, S., Raikar, V., Maguer, J.-F., and Le Corre, P.: Nitrogen uptake by size-fractioned plankton in permanently well-mixed temperate coastal waters, J. Plank. Res., 26, 12071218, doi:10.1093/plankt/fbh110, 2004.

Weiss, R. F. and Price, B. A.: Nitrous-oxide solubility in water and seawater, Mar. Chem., 8, 347-359, doi:10.1016/03044203(80)90024-9, 1980.

Weston, K., Jickells, T. D., Ferand, L., and Parker, E. R.: Nitrogen cycling in the southern North Sea: consequences for total nitrogen transport, Est. Coast. Shelf Sci., 59, 559-573, doi:10.1016/j.ecss.2003.11.002, 2004.

Wyatt, N. J., Kitidis, V., Woodward, E. M. S., Rees, A. P., Widdocombe, S. and Lohan, M.: Effects of high $\mathrm{CO}_{2}$ on the fixed nitrogen inventory of the Western English Channel, J. Plank. Res., 32, 631-641, doi:10.1093/plankt/fbp140, 2010 